\title{
Evolution of animal chemical communication: Insights from non- model species and phylogenetic comparative methods
}

\author{
Simon Baeckens \\ Laboratory of Functional Morphology, Department of Biology, University of Antwerp, \\ Universiteitsplein 1, 2610 Wilrijk, Belgium. \\ Email:simon.baeckens@uantwerp.be
}

\begin{abstract}
Chemical communication is probably the oldest, most ubiquitous form of information exchange in the natural world, spanning all three domains of life. While excellent sociobiological and behavioral ecological research has been conducted on the form and function of chemical signals in animals, we still know remarkably little on their evolution. Besides, much of our understanding of chemical signal diversity is restricted to insects, since studies on chemical communication in vertebrates are relatively scarce. In this review, I introduce the key concepts of animal communication and expand on the past, present, and future of research in chemical communication. When doing so, I highlight the current gaps in our knowledge on the evolution of the chemical communication system in animals, whilst emphasizing the heavy research bias towards lepidopterans. Here, I detail the benefits of using phylogenetic comparative methods to identify the motors and brakes that guide the evolution of chemical signals and chemical sensory systems. Moreover, I point out that focusing on non-model species in chemical ecology, specifically lizards, can provide valuable insights into how vertebrate chemical signals evolve, and how biological systems responsible for sending and receiving signals co-evolve with signal design. Lastly, I present a case study on lacertid lizards, demonstrating the possibilities of the phylogenetic comparative approach and the use of non-model species to study the evolution of animal chemical communication systems.
\end{abstract}

Keywords. Chemical signals, lizards, phylogenetic comparative methods, pheromones.

BAECKENS S. (2019). Evolution of animal chemical communication: Insights from non-model species and phylogenetic comparative methods. Belgian Journal of Zoology 149 (1): 63-93.

https://doi.org/10.26496/bjz.2019.31

\section{Animal communication}

From the time of DARWIN $(1859,1871)$, through the classic work of TINBERGEN (1953) and VON FRISCH (1967), to the extant greats such as WILSON (1965), animal communication has been a subject of profound interest to biologists. Whilst the study of animal signals began in earnest with Darwin's publication entitled The Expression of the Emotions in Man and Animals (DARWIN 1872), the phenomenon of animal communication has not gone unnoticed by early naturalists such as Aristotle and Pliny the Elder (reviewed by FöGEN 2014). Undoubtedly, it is the immense variety of birdsongs, frog calls, coral reef fish colours and extravagant displays of peacock spiders that have lured the attention of many scientists and laymen alike. Yet, despite decades of excellent and thorough research, genuine mystery still surrounds the evolution of animal signals and the origins of signal diversity. 


\section{Evolution of animal communication}

A signal can be defined as any structure that alters the behaviour or physiological status of other organisms, which evolved because of that effect, and which is effective because the receiver's response has also evolved, and whereby typically (but not always) both sender and receiver benefit from the information exchange (MAYNARD-SMITH \& HARPER 2003). According to the principles of Darwinian evolution, signals are selected for in such a way that they maximize the sender's fitness benefits, and this through their effect on the behaviour or physiology of receivers. Simultaneously, receivers use the same signals to try to increase their own fitness (JOHNSTONE 2000). Communication is stated as the act of sending and receiving signals.

Studying signal evolution, it is useful to make the distinction between the content of a signal, and its design (GUILFORD \& DAWKINS 1991, 1993). The content is what is being communicated, or the information on which the receiver makes a decision. For example, animals may transmit (true or false) information to others about mate quality, ability to fight or escape predators, reproductive and social status, and access to resources (BRADBURY \& VEHRENCAMP 1998). The design (or physical structure) of a signal allows the information to be effectively picked up and processed by the receiving animal (GUILFORD \& DAWKINS 1993). ARNOLD's (1983) adaptation paradigm on the link between variation in morphology, performance and fitness can easily be applied to signals, whereby design is equivalent to morphology and efficacy is equivalent to performance. In his seminal paper, Arnold suggested splitting the adaptation process into two components: a performance and a fitness gradient. Whereas the performance gradient measures the effect of variation in design on variation in performance, the fitness gradient measures the effect of variation in performance on fitness. Thus, in order to explain the origin of the diversity in animal signal design, it is important to firstly understand the 'performance gradient' by studying the relationship between variation in signal design and variation in signal efficacy, since those design features (with a genetic basis) that increase the efficacy of a signal component are expected to be selected upon. Still, most research on the evolution of animal communication has focused on signal content, while the functional design of signals has received far less attention (but see ESPMARK et al. 2000 and APPS et al. 2015).

Signal efficacy is affected by two main factors: (1) the environmental conditions under which the signal is emitted, transmitted and detected, and (2) the response properties of the sensory system of the receiver (ENDLER \& BASOLO 1998). The first step after signal production is the transmission of the signal through the medium, which can be air, water, vegetation or ground. Selection may favour signals that experience less attenuation, blocking, absorption, reflection, refraction and other distorting effects of the transmission medium. Signals are expected to evolve in order to minimize the effects of background noise and interfering signals from other species (ALBERTS 1992; ENDLER 1993; HUGHES et al. 2012; Fig. 1). Selection may also work indirectly to minimize environmental effects by favouring signalling behaviour during times and places at which detrimental factors are minimized. Once the signal reaches the receiver, it has to be picked up and processed. The sensitivity of the receptor system, together with the receiver's receptor condition (physiological state) and attentive status may influence how signals are processed, and whether and how the receiver will act upon a signal (ENDLER 1992, 1993). The receptor design is expected to evolve in order to 'optimally' detect and analyse the emitted signals of the sender (MAYNARD-SMITH \& HARPER 2003).

When considering communication as the sole driving force of the evolution of animals' emitting and sensory systems, we can expect strong correlated evolution between the signal and receptor design of animals. This is, however, not always the case as other forces are likely to influence the evolution of either side of the communication channel as well, and not necessarily in the same direction. This might bias or constrain the co-evolution of an 'optimized' signal-receptor system. For example, many animals use their sensory system, not only in the context of communication, but also for spatial orientation and to locate prey and predators (LEMASTER \& MASON 2001; SCHNITZLER et al. 2003). It seems unlikely that a 
single type of sensory system can optimize all the different functions. Rather, a particular receptor design is expected to represent a compromise, reflecting the relative ecological relevance of each function. Another potential selective force influencing signal design diversity that might disrupt the evolution of an 'optimized' signal-receptor system, is eavesdropping, which is the interception (and use of information) of signals intended for another individual (PEAKE 2005; Fig. 1). Eavesdroppers or 'emitter exploiters' are typically (but not exclusively) heterospecifics, such as predators or signal-homing parasites, that acquire information about others by actively heeding to their signalling interactions, usually to the cost of the signaller, but also to the receiver (HUGHES et al. 2012). While eavesdropping animals only benefit from strategies maximizing signal interception, selection favours the design of signals and receptors that minimize the signal reception by exploiters (ENDLER 1993). Therefore, when studying signal evolution, it is necessary to integrate the complete communication system, from the emitting to the receiving end, as this enables researchers to identify the different selective forces (and their respective importance) at play.

Thus, in order to explain the variation in animal signals, scholars should shed light on the ecological drivers and constraints that impact the evolution of animal signal design. This can be achieved (1) by examining the functional design of animal signals and the relationship between signal design and signalling environment, and (2) by assessing the diversity in receptor design, and the ecological factors influencing its variation.

Natural selection favours the design of signals that work efficiently (ENDLER 1992; BOUGHMAN 2002), whereas sexual selection favours signals that convey a maximum amount of information and that are good predictors of offspring fitness (POMIANKOWISKI 1988; GRAFEN 1990; STEIGER et al. 2011; CHEN et al. 2012; CLUTTON-BROCK \& HUCHARD 2013). Whilst animals only benefit from efficiently conveying information on their offspring fitness, natural and sexual selective forces do not necessarily drive the design of signals in the same direction. For example, a carotenoid-based orange colour may indicate

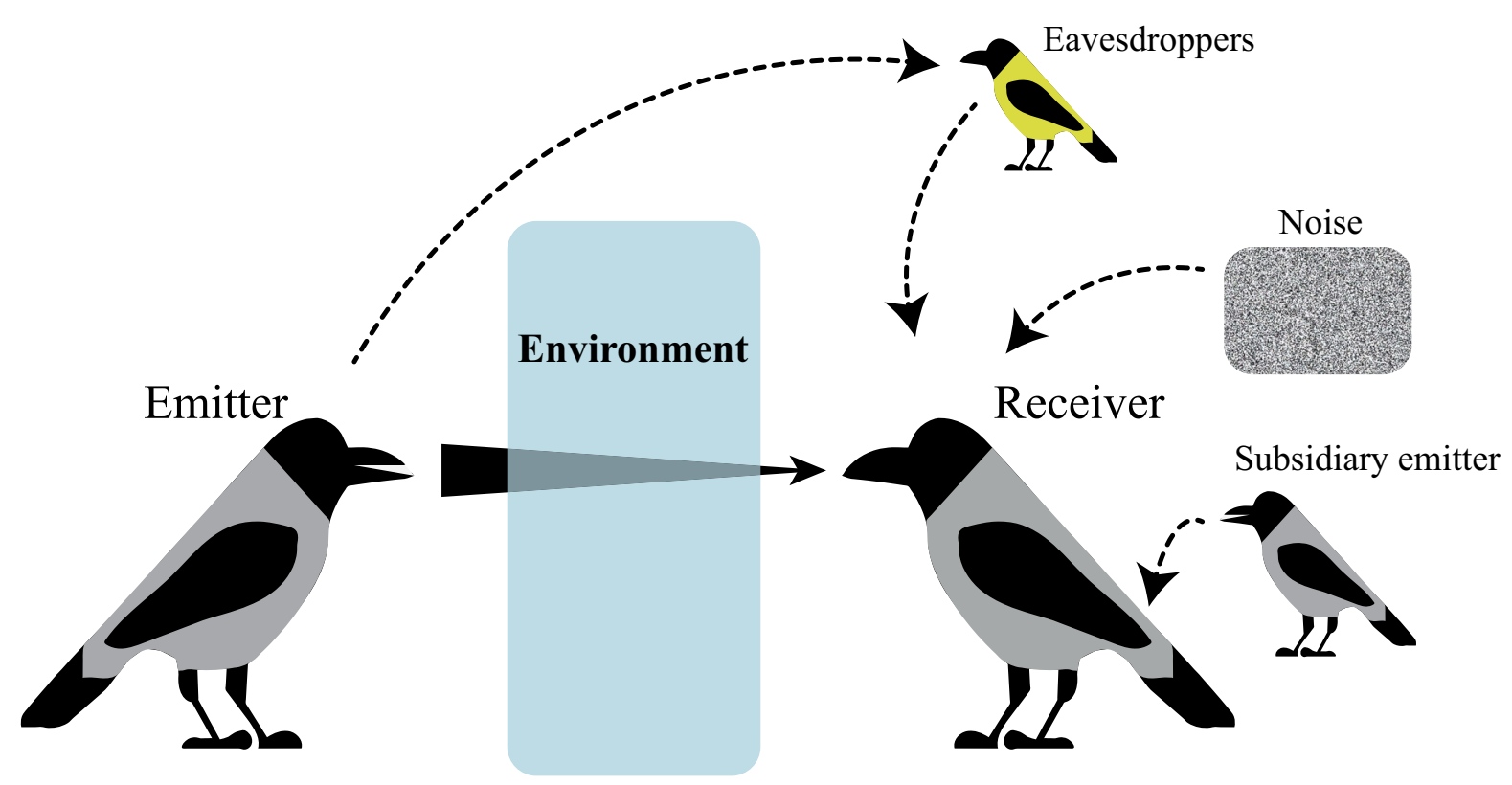

Fig. 1 - Schematic illustration of the components that affect the evolution of animal signal design. Efficacy-based selection favours those signalling features that maximize signal efficacy in a certain environment, that is: features that minimize environmental absorption, distortion, and interference, and minimize the effects of background noise, eavesdroppers, and signals from others (after ENDLER 1993). 
feeding success in a bird, but visual environmental conditions and spectral sensitivity may favour the use of the colour blue (ENDLER 1992).

Of course, not all components of signals are necessarily adaptive, as traits can be (phylo)genetically constrained or simply spandrels of San Marco (GOULD \& LEWONTIN 1979). Evidently, it is the interplay between selective and stochastic processes that shapes signal design divergence.

\section{Chemical communication}

Animals exploit a wide variety of modalities to communicate with one another, with the visual, auditory, and chemical communication systems being the most common modes of information exchange in the animal kingdom. The visually-oriented birds of paradise (Paradisaeidae), for instance, exhibit extraordinary ornamental plumage and sophisticated, often bizarre, display behaviours to signal their quality to conspecifics (SCHOLES 2008), and the highly venomous coral snakes (Micrurus fulvius) use their skin colouration as a warning signal towards predators (KIKUCHI \& PFENNING 2010). Some animals rely on their auditory system; grasshoppers and frogs produce complex calls and croaks to advertise their superiority (RYAN \& RAND 1995; RONACHER et al. 2008), wolfs howl to signal territory (HARRINGTON \& MECH 1979), and rattlesnakes rattle their tail to signal danger (SwAISGOOD et al. 1999). Many insects typically use their chemical communication system, with ants laying pheromone trails to guide nest mates to resources (WILSON 1965; REGNIER \& WILSON 1971), and male moths exploiting chemical signals to attract conspecific females (RAINA et al. 1989). A small number of animals utilize seismic (vibratory) signals to search for prey (e.g., golden mole, Eremitalpa granti; MASON \& NARINS 2002), to indicate threat (e.g., elephants, Elephantidae; O'CONNEL-RODWELL 2007) or during courtship (e.g., jumping spiders, Salticidae; ElIAS et al. 2003). While it is not unusual that a species exploits more than one signalling modality (multimodal communication; ROWE \& GUILFORD 1996; PARTAN \& MARLER 1999) in order to enhance the efficacy of a message (redundant-message hypothesis; JOHNSTONE 2000; ROWE 1999) or to convey several different messages (multiple-message hypothesis; HEBETS \& PAPAJ 2005), the majority of animal groups focus on a subset of modalities.

Most theoretical and empirical investigations of the evolution of animal signals have focused on visual and auditory communication. By contrast, evolutionary studies of chemical signals are less common, perhaps reflecting our own sensory biases or the increased technical complexity associated with analysing chemical signals (SYMONDS \& ELGAR 2008). Some authors have even argued that chemical communication is "the last frontier in the study of animal behaviour" (MOULTON 1968; HUNT et al. 2012). With the recent improvements in methods of chemical analysis (SCHULZ 2005), it is becoming increasingly clear that chemical signals are at play in multiple contexts in a wide variety of organisms, and that the diversity in chemical signal design is vast (MÜLLER-SCHWARZE \& SILVERSTEIN 1980; MÜLLER-SCHWARZE 2006; WELDON et al. 2008; WYATT 2010).

Chemical signals have several advantages over signals in other modalities. They work in darkness, around obstacles, and can be still operative in the absence of the signaller. Chemical signals can also cover large distances or last for long periods of time, ranging from days to months (MACDONALD et al. 1990; MÜLLER-SCHWARZE 2006). Chemical communication is probably the oldest and, possibly, the most ubiquitous form of information exchange in the natural world (WYATT 2014), and has been reported in bacteria (TAGA \& BASSLER 2003), fungi (BÖLKER \& KAHMANN 1993), plants (BALUŠKA 2009), and almost all animal groups: insects (WILSON 1965; REGNIER \& LAW 1968), molluscs (SUSSWEIN \& NAGLE 2004), crustaceans (BREITHAUPT \& THIEL 2011), spiders (TRABALON 2012), fish (SOLOMON 1977), amphibians (WOODLEY 2010), reptiles (MASON \& PARKER 2010), birds (CARO et al. 2015), and mammals (EISENBERG \& KLEIMAN 1972), including humans (COMFORT 1971). In the words of EISNER \& BERENBAUM (2002): "The vocabulary of living things is overwhelmingly chemical in nature". 
The origin of research on chemical communication dates to the second half of the $19^{\text {th }}$ century, when chemical ecologists, such as the Belgian Léo Errera and German Ernst Stahl, discovered that plant secondary metabolites play an important role in plant-insect interactions and suggested that plant chemical diversity evolved under the pressure of herbivory (FRAENKEL 1959; HARTMANN 2008). During the late 1950s, evolutionary entomologists dominated the field of chemical ecology, with E.O. Wilson taking the lead, concentrating on the role of pheromones in the social behaviour of insects (e.g., BARTH 1965; WILSON 1965). Chemical ecology became a well-established discipline by the end of the second millennium, with the rise of journals such as Journal of Chemical Ecology, Chemoecology, Chemical Communications and Chemical Senses. Currently, the proper analytical tools for studying natural products chemistry are available and affordable, permitting comprehensive taxon-wide research on the evolution of chemical signal diversity and design. Some might say that the sudden expansion of knowledge on the evolutionary biology of chemical communication is a direct consequence of the recent breakthroughs by molecular biologists (EISNER \& BERENBAUM 2002).

\section{Definitions}

Research on chemical signals brings together scientists from various fields with many different areas of expertise, from behavioural ecologists, through organic chemists, to neuroscientists, all bringing their own gobbledygook and concepts. Hence it is important to define a few terms that are often applied in the context of chemical communication at the outset. Here, I follow the classifications proposed by WYATT (2014).

A chemical involved in the chemical interaction between organisms is called a semiochemical. Some of the semiochemicals emitted by animals are chemical cues that are used as a guide to future action, but have not evolved for this purpose; only the receiver's response is evolved. Carbon dioxide in exhaled breath, for example, can be exploited as a cue by blood-sucking mosquitoes as a way of finding a host (GILLIES 1980). Semiochemicals that have evolved as signals for within-species communication are considered pheromones when these are individual molecules causing a specific reaction to the receiver, or signature mixtures when these are variable chemical mixtures containing a subset of the molecules in an animal's chemical profile. Semiochemicals acting between individuals from different species are called allelochemicals and can be further divided depending on the costs and benefits to the emitter and the receiver: allomones when the emitter benefits, but not the receiver; kairomones when the receiver benefits, but not the emitter; synomones when both the emitter and the receiver benefit.

\section{Emitting system}

Animal chemical signals (and cues) come from a bewildering variety of sources. Metabolites originating from excretions, such as urine and faeces, provide the energetically least expensive semiochemicals, and are used by many animals (LUCAS 1944). Male-male aggression in mice, for example, is triggered by a urinary mixture of 2-sec-butyl-4,5-dihydrothiazole and 3,4-hydro-exo-brevicomin (HARVEY et al. 1989), and faeces of the red fox (Vulpes vulpes) contain trimethylthiazoline, which alarms prey species (VERNET-MAURY 1980). However, most chemically-oriented animals have evolved a variety of specialised exocrine glands that produce secretions, which in turn carry chemical signals. The exocrine apparatus of social insects is well developed, with an impressive total of 105 different secretion glands, which clearly reflects the abundant use and importance of pheromonal communication in social insects (BILLEN 2006). The diversity of secretion glands in vertebrates is vast too, with each group having its own specialized gland system (MACDONALD et al. 1990; MÜLLER-SCHWARZE 2006). For example, most fish - not all - are equipped with caudal glands at the tail base (WEITZMAN \& FINK 1985), whereas many amphibians have three different types of glands in their cloacal area: cloacal, pelvic, and abdominal glands (KiKUYAMA et al. 1995). The most developed gland in birds is the uropygial gland, which primarily serves to waterproof their plumage, but also plays a role in intraspecific communication and as repellent for intruders (GABIROT et al. 2016). Turtles and tortoises possess Rathke's glands, although 
their role in producing chemical signals is still little explored (but see BRANN \& FADOOL 2006; IBÁÑEZ et al. 2014). Most snakes have paired scent glands that open into the cloaca, and some (e.g., Natrix and Macropisthodon) have 'nucho-dorsal' glands under the skin of the dorsal neck area (MADISON 1977), whereas many lizards are equipped with epidermal glands in their cloacal region (MAYERL et al. 2015). The most diverse collection of glands among vertebrates can probably be found in mammals, which encompasses ventral, tarsal, subauricular, metatarsal and axillary glands (MYKYTOWICZ \& GOODRICH 1974; EBLING 1988).

\section{Chemical compounds}

Chemical signals and cues may involve a wide variety of molecules, from volatiles to non-volatiles, encompassing all major chemical classes such as proteins, peptides, hydrocarbons, steroids, carboxylic acids, aldehydes, ketones, esters, phenols and ketals (BLOMQUEST \& BAGNÈRES 2010; APPS et al. 2015; WYATT 2015). A signal may consist of a single type of molecule, for instance cis-9-tetradecen-1-ol acetate, which is identified as the sex pheromone in the southern armyworm moth Prodenia eridania (JACOBSON et al. 1970), or cis-7,8-epoxy-2-methyloctedecane, which is a sex pheromone emitted by the gypsy moth Porthetria dispar (BIERL et al. 1970). However, many, probably most, chemical signals are not single compounds, but consist of a species-specific combination of molecules, sometimes even in a precise ratio. The combination is the signal. For example, the female sex pheromone of the Canadian red-sided garter snakes (Thamnophis sirtalis parietalis) consists of a homologous series of long-chain saturated and Z-monounsaturated methyl ketones (MASON et al. 1989), and the axolotl Ambystoma mexicanum emits multiple glycosylated sodefrin precursor-like factor proteins during courtship (MAEX et al. 2016). The sex pheromone of the oak leaf roller (Archips semiferanus) is identified as a specific blend (67:33 ratio) of trans-11- and cis-11-tetradecenyl acetates (MILLER et al. 1976).

\section{Receiving system}

From the slender antennae of the silk moth to the sizable nose of the saiga antelope, the sensory systems with which animals pick up chemical cues and signals from the environment vary dramatically among species. Yet, at the cellular level, chemosensation in all animals involves the same sequence of actions: (1) chemosensory receptors are exposed to the outside world in the membrane of chemosensory cells; (2) the arrival of a semiochemical, (3) which is converted into a signal by binding to a chemosensory receptor protein; (4) and finally, the signal is projected to a specific region in the brain via axons of the receptor neurons (HILDEBRAND \& SHEPHERD 1997; KRIEGER \& BREER 1999; KAUPP 2010).

The chief chemosensory systems (or organs) of terrestrial vertebrates are the main olfactory system and accessory olfactory system or vomeronasal system (ALLISON 1952; EISTHEN 1997; MÜLLER-SCHWARZE 2006). Both systems are located in the nasal region, and, although structurally distinct, their general organization is very similar: both possess specialized sensory epithelia for chemical uptake and neurone bundles for information transduction, and both project information to a specific area (bulb) in the brain for information processing (MORALES \& BACIGALUPO 1996). The main olfactory epithelium of amniotes is located in the nasal cavity, and is solely capable of detecting airborne volatile compounds; an action referred to as olfaction (or 'smelling' by lay). The vomeronasal organ, first described by Ludvig Jacobson in 1811 (TROTIER \& DøvING 1998), occurs in amphibians, mammals, reptiles, and embryonic birds. In snakes and lizards (Squamata) the vomeronasal organ is often well developed and capable of detecting volatile and non-volatile chemicals (SCHWENK 1993, 1995; COOPER 1995a, 1997a), sometimes referred to as vomerolfaction (COOPER \& BURGHARDT 1990). Squamate vomerolfaction is mediated by tongue-flicking behaviour in which the tongue samples substrate-bound or air-born chemicals in the environment and delivers them to the vomeronasal organs above the roof of the mouth (FILORAMO \& SCHWENK 2009). Unlike the main olfactory system, the vomeronasal system of squamates depends on the active, or voluntary, stimulation of the chemosensory organs by chemicals collected by the tongue (DAGHFOUS et al. 2012). Functionally, the main olfactory and vomeronasal system have different 
roles in the execution of several species-typical behaviours (HALPERN 1987). Excellent reviews and monographs describe and discuss the anatomy, function and evolution of chemoreception systems in invertebrate and vertebrates in great detail (see e.g., BOSSERT \& WILSON 1963; EISENBERG \& KLEIMAN 1972; KEVERNE 1999; KRIEGER \& BREER 1999; EISTHEN \& WYATT 2006; KAUPP 2010).

\section{Studying the evolution of chemical communication}

\section{Research approach}

Explaining the baffling diversity in animal phenotypes is one of the major challenges of evolutionary biology. While experimental evolutionary studies can explain the process of trait divergence on a small (intraspecific) scale (e.g., LAPIEDRA et al. 2018; BARRETT et al. 2019), only comparative biology may elucidate trait evolution on a macroevolutionary scale (CLUTTON-BROCK \& HARVEY 1979; LOSOS \& MILES 1994). In the absence of detailed time series, in which evolution of a trait can be traced directly through time, comparing current patterns of variation among species provides the best possible clues about a trait's evolutionary history, and the factors that may have driven or constrained its evolution (HARVEY \& PAGEL 1991). For the last thirty years, comparative biology has become widely appreciated and acknowledged as fundamental in studying evolution and adaption (HARVEY \& PURVIS 1991; GARLAND et al. 1992; Miles 1993; LOSOS \& MiLes 1994; SiH \& GLEESON 1995). The philosophy of comparative biology, however, is not novel, and can be easily traced back to Darwin and his famed 'Tree of Life' sketch (BARRET et al. 1987). This particular domain in science lies particularly strongly at the heart of some:

"The old-guard Feyerabend-esque naysayers who cling to the desperate belief that science is just the province of who can shout loudest, and most effectively corrupt and coerce others, all in pursuit of their favourite myths, should take stock of the field of comparative biology: combative, and yes, often petty and self-serving, it has in these past 25 years or so produced a steady, even if sometimes stumbling, triumph of the scientific method applied to this particular outpost of the field of evolution."

- MARK PAGEL (2014)

The comparative method is basically an analytical approach that studies species in a historical framework with the aim to elucidate the mechanism at the origin of their diversity. Species are typically the 'unit' of study in comparative research, but populations can be the focus as well (e.g., DRIESSENS et al. 2017). The main goal of comparative research is to investigate the adaptive significance of organismal traits by linking ecological variation with phenotypic trait variation. When comparative analyses indicate that species that inhabit similar environments resemble each other in a certain phenotypic trait, it is plausible to assume that this particular trait is an adaption to the environment: a product of evolution by natural selection. Of course, convergent evolution is not the only reason why species can have a similar appearance; common descent can lead to similarity between species' phenotypes too (CHEVERUD et al. 1985; HUELSENBECK et al. 2000; GoOLSBY 2015). It was already evident and recognized from the time of Darwin that patterns of interspecific variation cannot be interpreted without taking into account the underlying common descent of species. Remarkably, the application of this simple truth only became reality in the 1980s with the development of the statistical tools to do so; an uprising triggered by FELSENSTEIN's influential work on independent contrast (1985). Statistically, the effect of phylogeny on trait variation can be regarded as a confounding factor that violates assumptions about non-independence of the unit of analysis, and that potentially introduces spurious correlations across traits (FELSENSTEIN 1985, 2004). Now, with modern phylogenetic tools, comparative biologists can go well beyond 'statistically controlling for phylogeny' and can treat the evolutionary history of species as an interesting phenomenon on its own. Examining the biological diversity in the light of the phylogeny opens up horizons to explore, for instance, the correlated evolution of traits (e.g., DIAZ-URIARTE \& GARLAND 1996), phylogenetic signals in interspecific data (e.g., ReVELl et al. 2008), ancestral states 
(e.g., HuelsenBeCK \& Bollback 2001; PAGel et al. 2004), mode of trait evolution (e.g., O'MeARA 2012, O'MEARA et al. 2015), and rates of speciation/extinction and diversification (e.g., NeE et al. 1994; MADDISON et al. 2007). The use of phylogenetic comparative methods has become extremely popular over recent years (Fig. 2), with statistical improvements to the existing methods being published almost weekly (COOPER et al. 2016). Hand in hand with the wealth of open-access genetic information (e.g., GenBank ${ }^{\circledR}$ ) and reliable phylogenies of numerous animal groups, even at low taxonomic level, the field of comparative biology is blossoming as never before (BENSON et al. 2009; SAYERS et al. 2009). For further resources and guidance, I encourage scholars new to the field to turn to some of the seminal work of Luke Harmon (e.g., HARMON 2018), the online blog of Liam Revell (http://blog.phytools.org), and the book 'Concepts and Practice' by GARAMSZEGI (2014).

Phylogenetic comparative methods have also found their way into the field of animal communication. An excellent study by GARAMSZEGI et al. (2005), for example, compares the song repertoire of 39 passerine bird species with their respective brain size, and establishes that species with highly complex songs tend to have large intersexual differences in brain size. Another comparative analysis, now on the visual display behaviour of 53 anole lizard species, shows that lizards' display duration is linked with their level of sexual size dimorphism, and that the amount of environmental light in which displays are performed affects the display complexity of a lizard (ORD \& MARTINS 2006). In an attempt to unravel the factors influencing the diversity of advertisement calls in dart-poison frogs (Dendrobatidae), ERDTMANN \& AMÉZQUITA (2009) show that variation in call traits cannot be explained by ecological variation, but find species' calls to be highly phylogenetically informative; meaning that, a strong relationship exists between how closely related species are and how similar they are in any feature of the advertisement call - an outcome only made possible by the use of phylogenetic comparative tools. Surprisingly, multispecies comparisons of the design of chemical signals are almost entirely lacking. This is probably due to the combination of only very recent developments in chemical analytical and statistical comparative tools, and the time researchers need to assemble a large-scale multi-species chemical dataset. A recent study by WEBER and colleagues (2016) on perfume signalling in orchid bees (Euglossa) is one of the first studies on the macroevolution of chemical signal design in animals, and the factors influencing design diversity. Based on the chemical composition of the chemical signals of 65 Euglossa species,

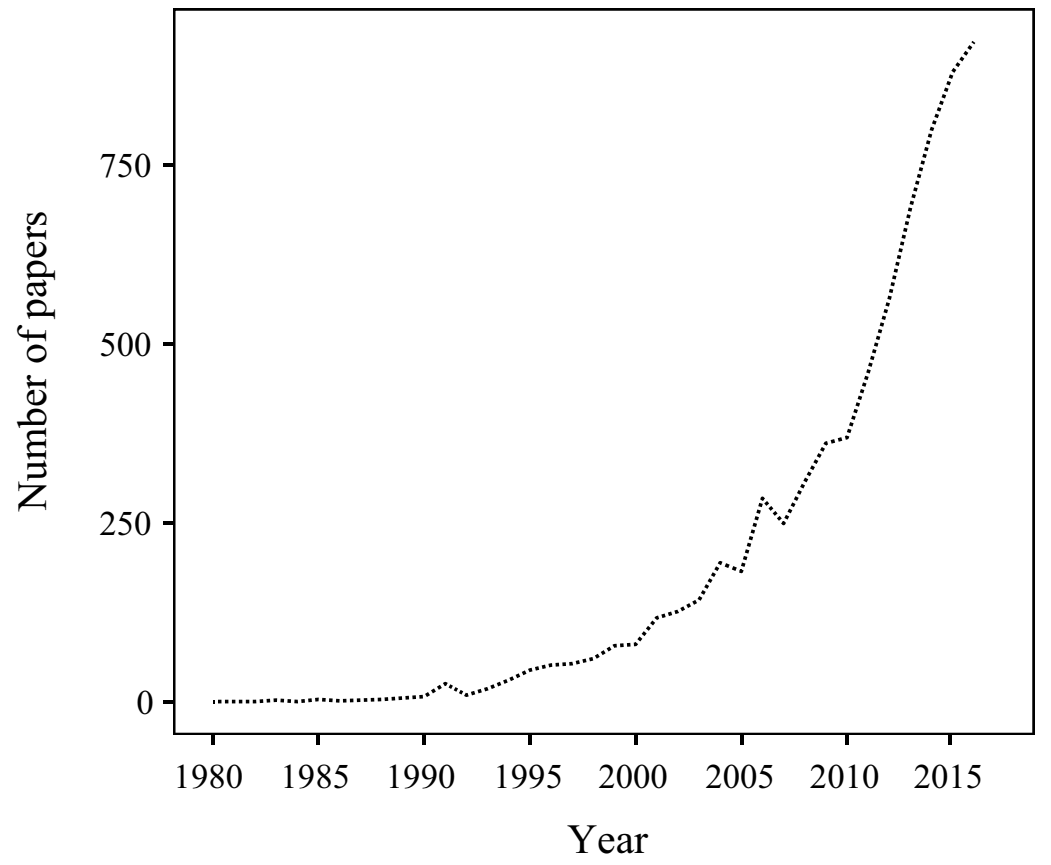

Fig. 2 - The number of papers containing the phrase 'phylogenetic comparative' published each year from 1980 to 2016. Data obtained from COOPER et al. 2016. 
WEBER et al. (2016) suggest that the evolution of species-specific signal design in Euglossa is rapid, is impacted by sympatric Euglossa species, and may be a function of both a burst of chemical signal divergence early in speciation and subsequent reproductive character displacement.

The sensory system has also been subjected to phylogenetic comparative analyses. Excellent studies have been published on the evolution of vertebrate eyesight (e.g., BOWMAKER 2008; FERNANDEZ \& MORRIS 2007; SiMÕES et al. 2015, 2016) and hearing (DoOLING \& FAY 2000; BoHN et al. 2006), and on the main olfactory and vomeronasal system too (EISTHEN 1997). Research has focussed on several aspects of the latter two sensory systems: size of the bulbs in the brain (e.g., GITTLEMAN 1991; BARTON et al. 1995), size of the organs themselves (e.g., SCHLUESSEL et al. 2008), structure and type of receptor cells in the epithelia (e.g., EISTHEN 1992; COOPER 1997b), and morphology of the chemical sampling devices (e.g., SCHWENK 1994a, 1994b; COOPER 1995a).

Tests on the hypothesis that the design of the signal receiving system of animals is evolved to 'optimally' detect and process the emitted signals, have been limited to within-species analyses or comparisons of two species. For example, VOGT \& RIDDIFORD (1981) showed that both the morphological and biochemical design of the antennae of male silk moths (Antheraea polyphemus) are maximally tweaked to the sex pheromone $[11,12-\mathrm{H}]$ trans- 6 ,cis-11-hexadecadienyl acetate emitted by conspecific females, which enables long-distance detection (up to $4.5 \mathrm{~km}$ ). Evidence for co-adaptation between signal and receptor design was also found in the Tungara frog (Physalaemus pustulosus), where the low frequency mating call of male frogs is exactly tuned to stimulate the inner ear receptor organ of females of the same species (RYAN et al. 1990). Although valuable, studies focussing on one species lack the wider insight that can be gained from multi-species comparative studies. The few studies that opted for a broad taxon-wide comparative approach examined correlated evolution between signal and sensory design in the hearing sensitivity and social calls of bats, frogs and katydids (WILCZYNSKI et al. 2001; BOHN et al. 2006; MonTEALEGRE-Z 2009). To my knowledge, no study to date has examined this hypothesis for the chemical communication system (but see case study on page 75 ).

\section{Lizards as study model}

\section{From an evolutionary point of view}

Lizards have starred in many research branches of evolutionary biology, and have proven excellent models for studying locomotion performance (e.g., VAN DAMME et al. 1997; IRSCHICK \& LOSOS 1998; VAN DAMME \& VANHOOYDONCK 2001), feeding mechanics (e.g., AERTS et al. 1997; HERREL et al. 2001, 2007a), life-history patterns (e.g., SHINE 1980; BAUWENS 1999; MESQUITA et al. 2016a, 2016b), thermal physiology (e.g., VAN DAMmE et al. 1990; SCHEERS \& VAN DAMme 2002; VerwaiJen \& VAN DAMme 2007a; HERREL et al. 2007b), developmental (in)stability (e.g., VERVUST et al. 2008; LAZIĆ et al. 2015), island evolution (e.g., MeIRI 2007; PAFILIS et al. 2009; VERVUST et al. 2009; NovOSOLOV et al. 2016) and foraging behaviour (e.g., HUEY \& PIANKA 1981; PERRY 1999; VITT et al. 2003; COOPER 2005). Some lizard taxa have played a pioneering role in our current understanding on the powers of natural selection, such as the genus Anolis on adaptive radiation (LOSOS et al. 1998; LOSOS \& RICKLEFS 2009).

Students of animal communication have also repeatedly used lizards as model organisms. This is hardly surprising as the diversity and complexity of the signals and displays exploited by lizards is vast. Understandably, the majority of studies on lizard communication focus on the visual and chemical communication systems, since lizards rely more strongly on those two modalities for everyday activities. Nevertheless, some lizards produce sounds (WEVER et al. 1963), although this is predominantly restricted to Gekkota (but see LABRA et al. 2013; BAECKENS et al. 2019), as they are unique among lizards in having laryngeal specializations for vocalization and well-developed auditory sensitivity (reviewed by FRANKENBERG \& WERNER 1991). Research on the visual modality of lizards has broadened our knowledge on the evolution of colour polymorphism (e.g., SINERVO \& LIVELY (1996) 
on Uta stansburiana; HuYGHE et al. (2007) on Podarcis melisellensis), Batesian mimicry (e.g., HuEY \& PIANKA (1977) on Heliobolus lugubris), colour crypsis (e.g., STUART-Fox et al. 2008 on Bradypodion taeniabronchum), and visual signal design and efficacy (e.g., NICHOLSON et al. 2007; DRIESSENS et al. 2017 on Anolis), to name a few. In contrast to the number of studies on visual communication in lizards, the literature on lizard chemical communication is relatively meagre, although it is a major factor in the life of many lizard species. However, in recent years, the discipline of chemical communication in reptiles has been growing (MASON \& PARKER 2010; MARTÍN \& LÓPEZ 2014).

Within vertebrates, lizards are a promising clade to study the evolution of chemical communication, and for various reasons. Consider four. Firstly, lizards use chemical cues and signals during a variety of activities, such as prey detection or foraging, predator detection, species and individual recognition, mate choice, and territoriality (reviewed by MASON 1992; MASON \& PARKER 2010). Secondly, aside from the faeces, cloacal secretions, and skin lipids that contain socially relevant chemical stimuli (MASON \& PARKER 2010), many lizards possess specialized glands in the dermis of their inner thighs, which produce waxy secretions involved in chemical signalling (reviewed by COLE 1966; MAYERL et al. 2015). Thirdly, the chemoreception system of many lizards is highly sophisticated, comprising of a welldeveloped olfactory and vomeronasal system for chemical processing, and a forked tongue for chemical sampling (SCHWENK 1993, 1995; COOPER 1995a, 1996; Fig. 3). Both sensory systems are, furthermore, functionally interrelated (HALPERN \& MARTíNEZ-MARCOS 2003), with (volatile) scent stimuli being first received through the nares and processed by the olfactory organs, which in turn triggers tongue-flickmediated vomerolfaction (HALPERN 1992; COOPER 1994; SCHWENK 1995). Fourthly, the interspecific variation in chemical signal design, investment in chemical signalling, development of the chemoreception system, and overall reliance on chemical communication, appears considerably large (SCHWENK 1995; COOPER 1997a, 1997b; VITT \& PIANKA 2005; MARTíN \& LÓPEZ 2014). In spite of that, lizards are still underrepresented in the field of chemical ecology, where the literature is heavily biased towards insects. A literature search by SYMONDS \& ELGAR in 2008 revealed that $79 \%$ of the studies on pheromone diversity have focussed on insects, while less than $1 \%$ examined lizards. The exceptional research interest for insect pheromones is most likely the result of its economic value as an application in pest management, rather than its biological value to understand the evolution of chemical communication.

Nevertheless, the chemosensory system of lizards has received some attention in the past, with the lingual system being the main focus due to its significance in the evolutionary history of squamates (Fig. 4). The central role of the tongue is nicely illustrated by the fact that families of lizards and snakes

(a)

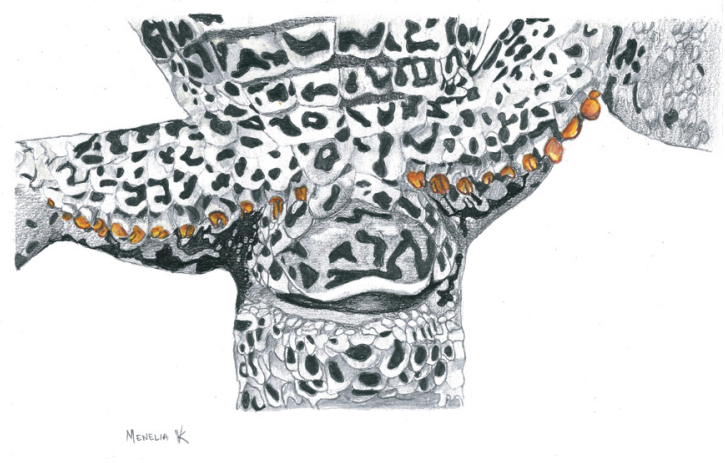

(b)

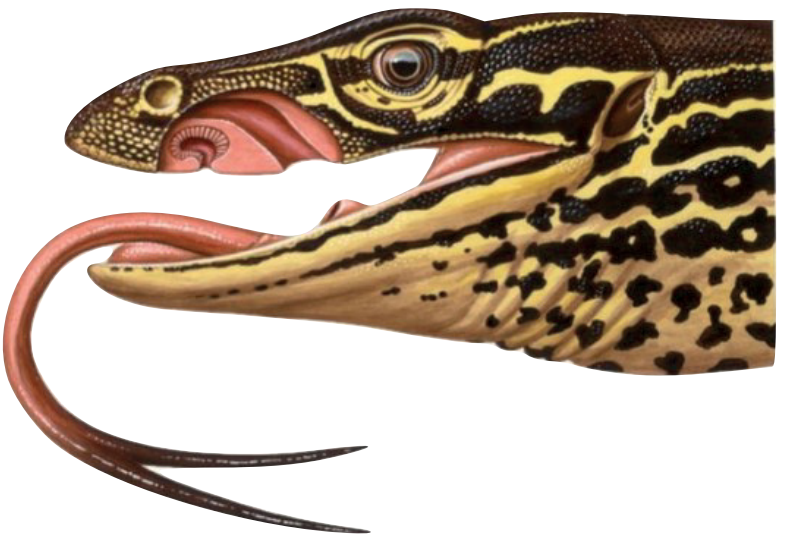

Fig. 3 - An illustration of the chemosignalling and chemoreception systems of lizards, with respectively (a) two rows of femoral pores on the inner thighs of a male lacertid (illustration made by Menelia Vasilopoulou-Kampitsi) and (b) a tongue-flicking varanid showing its olfactory and vomerolfactory system on a lateral section. 
have traditionally been attributed to either the more 'primitive' 'Iguania' (a group with fleshy tongues used in prey capture, a sit-and-wait foraging strategy, and relatively limited chemoreceptive abilities) or the 'derived' 'Scleroglossa' (that use their jaws to capture food, have a forked tongue for vomerolfaction, and forage actively). Whether the 'Iguanian' characteristics are truly ancestral, and the 'Scleroglossan' ones derived, is a matter of debate (Losos et al. 2012), but, at least at the family level, there is strong evidence for correlated evolution between squamates' mode of foraging and the degree of development of their vomeronasal-lingual system (SCHWENK 1994a, 1994b, 1995; COOPER 1995a, 1995b, 1997a). Of course, the strict and conservative separation of 'chemically-oriented' 'Scleroglossa' (comprising all Gekkota, Lacertoidea, Scincoidea and Anguimorpha) and 'visually-oriented' 'Iguania' seems flawed in the sense that many 'scleroglossans' also have excellent eyesight (PÉREZ I DE LANUZA \& FONT 2014; MARTIN et al. 2015) and frequently use visual displays (COOPER et al. 2003; FONT et al. 2012b), while many 'iguanians' also use chemical cues to discriminate among prey items (COOPER \& LEMOS-ESPINAL 2001) and in intraspecific communication (SIMON et al. 1981; DUVALL 1979; BAECKENS et al. 2016).

While the chemosensory system of lizards has been the topic of several studies in the past, comparative research on the chemosignalling system and chemical signal design in lizards is almost completely lacking (but see PINCHEIRA-DONOSO et al. 2008 and see case study on page 75). Besides, the recent molecular phylogeny of squamates proposed by ZHENG \& WIENS in 2016, which is fundamentally discordant with the morphology-based phylogeny suggested by GAUTHIER et al. (2012), partially tackles the insights gained from earlier studies on the evolution of squamate chemoreception in the 1990s by 'tongue-specialists' K. Schwenk and W.E. Cooper, Jr. In addition, while Schwenk's and Cooper's research provided us with excellent data on squamates' tongue morphology and use, none of the studies has explored this at a lower taxa level, e.g., within a family. Therefore, it is unclear how sensory systems change on relatively small evolutionary time scales. Cleary, this calls for comprehensive research on the evolution of lizard chemical communication, integrating all aspects of communication (emitting system,
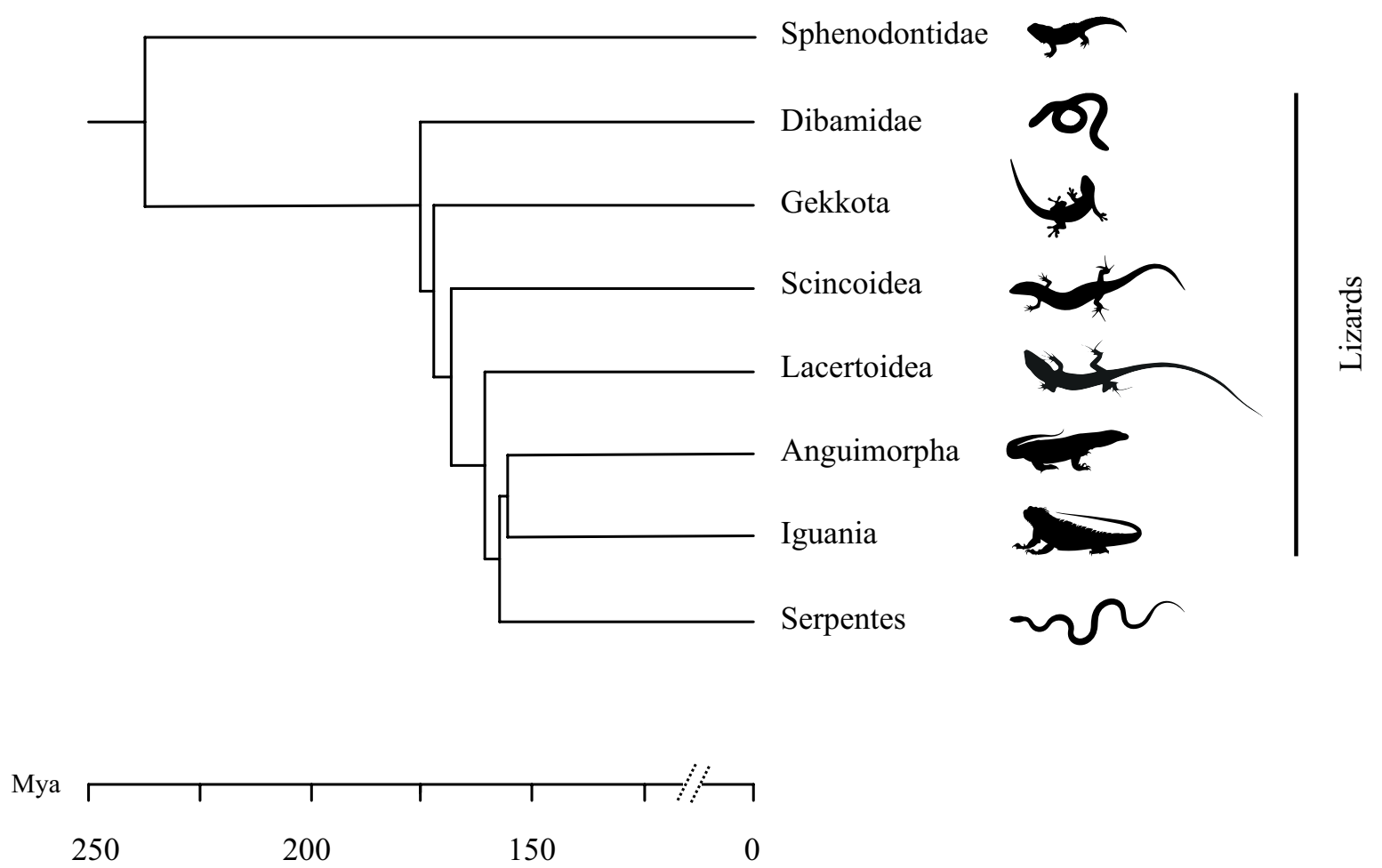

Fig. 4 - Time-calibrated lepidosaurian phylogeny presenting Sphenodontidae and all squamate infraorders. Note that 'lizards' are a paraphyletic taxonomic group. Molecular phylogeny based on ZHENG \& WIENS (2016). 'Mya' = million years ago. 
signal design, receiving system), by taking a phylogenetic interspecific comparative approach while concentrating on one specific lizard family.

The family Lacertidae constitutes an excellent group of lizards for studying the evolution of chemical communication. Lacertids rely intensely on chemical cues for predator avoidance (e.g., VAN DAMME \& QUICK 2001; AMO et al. 2004a, 2004b, 2004c; MARTín et al. 2015a), prey detection (e.g., COOPER \& PÉREZ-MELLADO 2002b; VERWAIJEN \& VAN DAMME 2007b), and on chemical signals for many aspects of inter- and intraspecific communication (reviewed by MARTín \& LOPÉZ 2014). All lacertid species (except one: Meroles anchietae) are equipped with follicular epidermal ('femoral') glands on their inner thighs, which produce a waxy cocktail of proteins and lipids that is actively, or passively, deposited on the substrate (MASON \& PARKER 2010; DE VILLIERS et al. 2015; MANGIACOTTI et al. 2019). Recent analyses have revealed that these femoral gland secretions operate as chemical signals that are involved in a variety of social contexts, such as territory demarcation and assessment (ARAGÓN et al. 2001a; FONT et al. 2012a; MARTÍN \& LÓPEZ 2012), male rival assessment (LÓPEZ \& MARTÍN 2002; CARAZO et al. 2007; KHANNOON et al. 2011), female choice (CARAZO et al. 2011; KOPENA et al. 2011, 2014; GABIROT et al. 2013; MARTíN \& LÓPEZ 2013, 2015), assessment of female reproductive status (COOPER \& PÉREZMELLADO 2002a), individual recognition (GABIROT et al. 2010a, 2010b), sex identification (KHANNOON et al. 2010) and species recognition (BARBOSA et al. 2006; GABIROT et al. 2010b).

Moreover, the biogeographic history and substantial ecological radiation of lacertids (ARNOLD 1989a, 1989b) may provide a valuable opportunity for researchers to examine the environmental factors driving the evolution of lizard chemical communication. Distributed over most parts of the Old World, more than 320 lacertid species, assigned to 42 genera, have successfully radiated into a wide array of habitats and climate regions; from subarctic tundra through temperate heathlands and forests, alpine meadows and Mediterranean maquis, steppe and gravel semi-deserts, and monsoonal rainforest to sandy dune systems in the desert (ARNOLD 1989a, 1989b; HARRIS et al. 2002). Within these habitats, lacertids utilize a great diversity of microhabitats and substrates, ranging from herby vegetation over stony undergrounds to shifting sands. Other species climb extensively in shrubs or trees (VANHOOYDONCK \& VAN DAMME 1999; VANHOOYDONCK et al. 2009). Although most lacertids share the same general morphology and many aspects of their ecology (e.g., diurnal, heliothermic, oviparous; CASTILLA et al. 1999; VAN DAMME 1999; VITT \& PIANKA 2007), they appear to differ in colouration and conspicuousness (PÉREZ I DE LANUZA \& FONT 2010, 2015, 2016), sexual size dimorphism (PÉREZ I DE LANUZA et al. 2013), foraging mode (Huey \& PianKa 1981, Perry et al. 1990; PERry 1999; VerWAiJen \& VAN DAMME 2007a, 2007b, 2008), anti-predator behaviour (VANHOOYDONCK \& VAN DAMME 2003), and even some aspects of their diet. Although most lacertids have a predominantly arthropod-based diet, the relative contribution of different types of arthropods varies considerably among species (DíAZ 1995; CARRETERO 2004; HERREL et al. 2004) and some species, especially (but not exclusively) islanddwellers consume large amounts of plant material (PÉREZ-MELLADO \& TRAVESET 1999; VAN DAMME 1999; HERREL et al. 2004). Although prey availability undoubtedly steers much of the interspecific variation in diet in lacertids, several species have been shown to prefer or avoid certain food items (see CARRETERO 2004 for a review).

\section{From a practical point of view}

Most lacertid species are widespread and locally abundant, although some desert species may hold low-density populations (PIANKA 1971; pers. obs.). With the proper amount of speed, commitment, coordination and flair, lacertids are fairly easy to capture in the wild by hand or noose (i.e., a fishing rod and a tiny nylon snare to hurl around the lizard's neck, GARCÍA-MUÑOZ \& SILLERO 2010). Alternative catching techniques have been used (e.g., sling shots, 'lizard grabber', 'whomping'; PIANKA 1994; WITZ 1996), but are now out-dated or considered unethical ${ }^{1}$. Generally, keeping lizards in captivity

\footnotetext{
${ }^{1}$ Pianka (1994) on catching lizards in the Outback of Australia: "For much of my research, it is essential that I collect the animal for a permanent museum specimen, dead or alive, in any way possible, so I often shoot lizards with either a BB gun or .22-caliber dust shot."
} 
does not pose any great difficulty and they appear to behave 'naturally' in experimental set-ups. In addition, lizards require relatively little food and space. These characteristics enable herpetologists to obtain valuable information on a large number of individuals in a reasonable short time span.

\section{Case study}

Early investigations on a limited number of species revealed considerable differences in the chemical composition of the glandular secretions in lacertid lizards (MARTín \& LÓPEZ 2014), and in several aspects of the chemical emitting and receiving system of lizards (SCHWENK 1993, 1995; COOPER 1995a, 1997a). Since only recently, the evolutionary processes causing this disparity were largely unknown.

From 2015 on, I started to quantify the diversity in the design of the lizard chemical communication system in order to examine the phylogenetic constraints and ecological drivers that influence the evolution of this diversity. I approached this question by integrating the three components of communication: emitting system $\rightarrow$ signal design $\rightarrow$ receiving system. Based on histological sections and literature data, I, first, documented variation in absence/presence of epidermal glands, gland size, and number of glands in lizard species. Phylogenetic comparative tests indicated a strong and significant phylogenetic signal in epidermal gland number among lacertids, with no effect of climate on interspecific variation in gland number. In contrast, substrate use did affect gland number with shrub-climbing species having fewer glands than species inhabiting other substrates (BAECKENS et al. 2015). Second, using gas chromatography-mass spectrometry (GC-MS), I established the existence of vast disparity in the chemical composition of the glandular secretion of 64 lacertid lizards, distributed over Africa, Asia and Europe (Fig. 5).

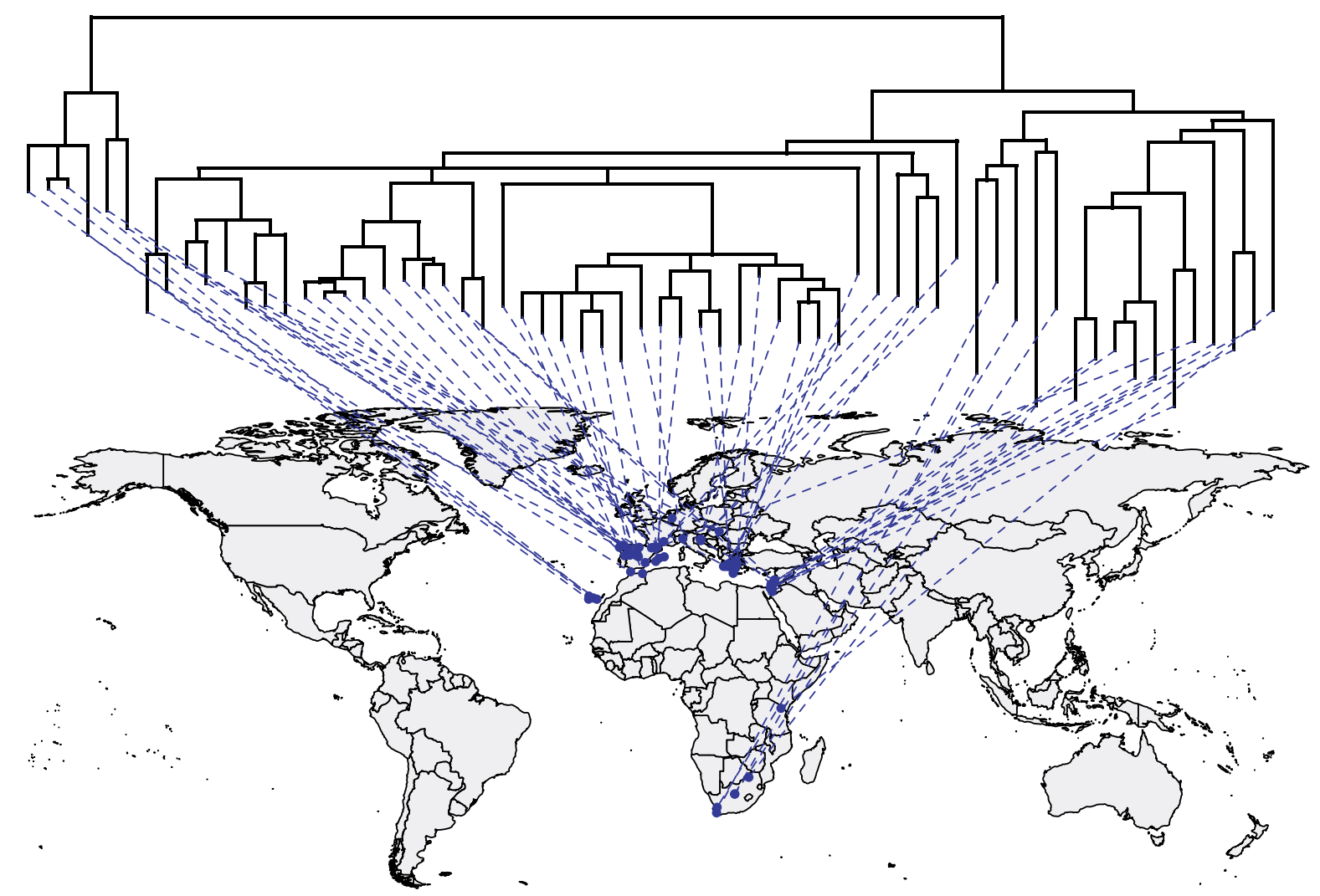

Fig. 5 - A projection of the lacertid phylogeny onto a geographic world map, in which the tops of the tree are connected to the catch-locations of the lizards on the map via dotted lines (data from BAECKENS et al. 2018a). 
Comparative statistics showed that despite the strong phylogenetic signal in chemical signal design, variation in climatic conditions best explained the interspecific variation in signal design (BAECKENS et al. 2018a). Specifically, species living in hot, dry environments contained higher proportions of stable compounds of high molecular weight in their secretions (Fig. 6). Hot and dry conditions increase evaporation rate of chemicals, subsequently, decreasing the longevity of a signal. Stable and heavyweight compounds most likely experience reduced evaporation rates and counteract the rapid signal fade-out through evaporation, generating a highly persistent scent-mark. By contrast, species inhabiting wet, humid conditions produced highly aromatic secretions containing numerous different compounds of low molecular weight (Fig. 6). Such chemical mix probably creates a volatile-rich signal that can be used for long-distance airborne communication. Additional statistical analyses were unable to establish any correlative evidence for a link between interspecific variation in signal design and other biological drivers, such as dietary composition (BAECKENS et al. 2017a) and intensity of sexual selection (based on the degree of sexual size dimorphism; BAECKENS et al. 2018b).

Third, behavioural observations combined with data from previous work revealed considerable interspecific variation in the chemoreceptive behaviour of lizard species. Specifically, I provided evidence that foraging mode, not phylogenetic relatedness drives convergent evolution of similar levels of chemosensory investigation in lizards and snakes (BAECKENS et al. 2017b). The findings of this study showed that baseline tongue-flick rate (TFR) is higher in active than ambush foragers. Although baseline TFR appeared phylogenetically stable in some lizard taxa, this turned out to be a consequence of concordant stability of foraging mode: when foraging mode shifts within taxa, so does baseline TFR. In addition, I found that baseline TFR is a good predictor of prey chemical discriminatory ability, as I established a strong positive relationship between baseline TFR and TFR in response to prey. Fourth, I observed substantial differences in the vomerolfactory-lingual system of lacertid lizards on the basis of tongue measurement and micro-CT images of the vomeronasal organs. Although the results imply independent evolution of tongue and vomeronasal-organ form, I did find some evidence for co-variation between sampler and sensor, i.e., tongue forkedness was correlated with the thickness of the sensory epithelium of the vomeronasal-organ (BAECKENS et al. 2017c).

Overall, the findings of this research project showed that the design of the chemical communication system of lizards varies considerably among species, and appears to have evolved relatively quickly (BAECKENS et al. 2015; 2017a, 2017b, 2017c; 2018a, 2018b; GARCí-ROA et al. 2017). Searching for evolutionary patterns of variation, I found that comprehensive phylogenetic comparative analyses were unable to ascribe interspecific variation in the chemical signal design of lacertids to among-species

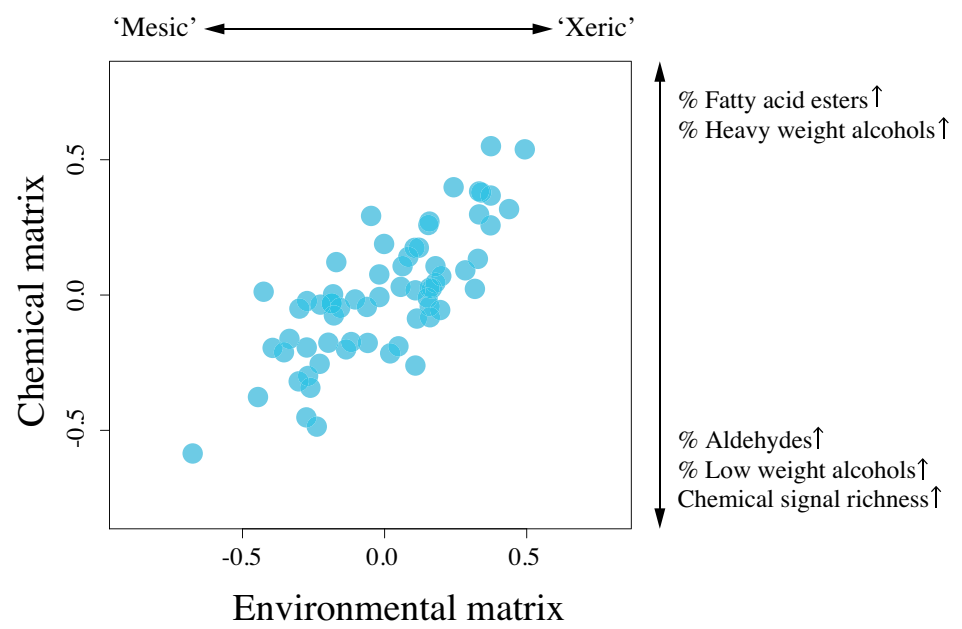

Fig. 6 - Scatterplot showing the significant relationship between the chemical composition of the glandular secretions of lacertid lizards and the environment they inhabit (modified from BAECKENS et al. 2018a). For details on the interpretation of the figure, see BAECKENS et al. 2018a. 
differences in diet (BAECKENS et al. 2017a) or intensity of sexual selection (BAECKENS et al. 2018b). Conversely, I established convincing evidence for an important role of the climatic environment in explaining variation in the chemical signalling system of lacertids (BAECKENS et al. 2018a), which might result from differential selection on signal efficacy; the ability of signals to travel efficiently through the medium and to attract the attention of the receiver. These findings provide evidence for convergent evolution in the chemical signalling system of lacertid lizards; a result revealed by the use of a phylogenetic comparative approach.

Lizards rely on their chemoreception system to sample chemical signals from the surroundings for communication purposes, yet, some species also use their chemical senses to forage. The foraging mode of lizards strongly predicted interspecific variation in vomerolfactory behaviour (tongue-flick rate) (BAECKENS et al. 2017b), but not vomeronasal-lingual morphology (BAECKENS et al. 2017c). However, the latter was related with species degree of investment in chemical signalling, cautiously hinting for co-evolution between the signal emitting system and signal receiving system, hence the evolution of an 'optimal' communication system (BAECKENS et al. 2017c).

While this work has shed initial light on the macro-evolutionary processes moulding variation in the design of the chemical communication system of lacertid lizards, there are still numerous questions to be answered in further research studies. For instance, it would be worthwhile to examine the relationship between species' investment in chemical signalling system (gland number, chemical signal design) and conspicuous body colouration to assess whether there is a trade-off between investments in signalling modalities. Moreover, comparative statistics can aid in examining the potential effect of eavesdropping predators on the evolution of the lizard chemical communication system. No studies have attempted to investigate the potential costs of the use of scent-marks in lizards with regards to chemical eavesdropping. Scholars could study whether high predatory environments (inhabited by chemically-oriented hunters, such as snakes) impact the evolution of the emitting system or signal design of lizards in any way. More advanced phylogenetically-informed statistics can test whether the evolution of certain features of the chemical signalling system have influenced diversification and speciation rate in lizards. Clearly, there has never been a better time than now to be a comparative chemical ecologist.

\section{Outlook}

Traditionally, researchers have taken a sociobiological and behavioural ecological approach to study various aspects of chemical communication in a few focal animal species. Today, with the recent improvements in methods of chemical analysis and bio-imaging (SCHULZ 2005, EGGELING 2018), researchers can now also turn to the phylogenetic comparative method and perform large-scale amongspecies comparisons allowing macro-evolutionary studies of chemical communication. Insects have typically been the go-to subjects of study in the field, but researchers should be encouraged to examine non-model species, such as lizards, as they can provide excellent groups to investigate the drivers and constraints that guide the evolution of the systems responsible for sending out and receiving signals.

\section{Acknowledgments}

The author thanks Raoul Van Damme, Peter Aerts, Katleen Huyghe, Panayiotis Pafilis, José Martín, and Stefan Van Dongen, as well as three anonymous reviewers for significantly improving drafts of this manuscript, Menelia Vasilopoulou-Kampitsi for the artwork, Josie Meaney for linguistic advice, and the Royal Belgian Society for Zoology for inviting me to write this review. This work was part of Simon Baeckens' doctoral thesis at the University of Antwerp, which was made possible through financial support from the University of Antwerp. Simon Baeckens is currently a FWO postdoctoral fellow (12I8819N) at the Functional Morphology lab (University of Antwerp). 


\section{References}

Aerts P., Herrel A. \& De VReE F. (1997). Ecomorphology of the lizard feeding apparatus: a modelling approach. Netherlands Journal of Zoology 48: 1-25. https://doi.org/10.1163/156854298X00183

AlBERTS A.C. (1992). Constraints of the design of chemical communication systems in terrestrial vertebrates. The American Naturalist 139: 62-89. https://doi.org/10.1086/285305

ALLISON A. (1952). The morphology of the olfactory system in the vertebrates. Biological Reviews 28: 195-244. https://doi.org/10.1111/j.1469-185X.1953.tb01376.x

AMO L., LÓPEZ P. \& MARTín J. (2004a). Wall lizards combine chemical and visual cues of ambush snake predators to avoid overestimating risk inside refuges. Animal Behaviour 67 (4): 647-653. https://doi.org/10.1016/j.anbehav.2003.08.005

AMO L., LÓPEZ P. \& MARTín J. (2004b). Thermal dependence of chemical assessment of predation risk affects the ability of wall lizards, Podarcis muralis, to avoid unsafe refuges. Physiology \& Behavior 82 (5): 913-918. https://doi.org/10.1016/j.physbeh.2004.07.013

AMO L., LÓPEZ P. \& MARTÍN J. (2004c). Chemosensory recognition and behavioral responses of wall lizards, Podarcis muralis, to scents of snakes that pose different risks. Copeia 2004 (3): 691-696. https://doi.org/10.1643/CE-03-220R1

Apps P.J., WeLdon P.J. \& KRAMER M. (2015). Chemical signals in terrestrial vertebrates: search for design features. Natural Products Reports 32: 1131-1153. https://doi.org/10.1039/c5np00029g

ARAGÓN P., LÓPEZ P. \& MARTín J. (2001). Effects of conspecific chemical cues on settlement and retreat-site selection of male lizards, Lacerta monticola. Journal of Herpetology 35: 681-684. https://doi.org/10.2307/1565912

ARNOLD E.N. (1989a). Systematics and adaptive radiation of equatorial African lizards assigned to the genera Adolfus, Bedriagaia, Gastropholis, Holaspis and Lacerta (Reptilia, Lacertidae). Journal of Natural History 23: 525-555. https://doi.org/10.1080/00222938900770311

ARNOLD E.N. (1989b). Towards a phylogeny and biogeography of the Lacertidae: relationships within an Old-World family of lizards derived from morphology. Bulletin of the British Museum (Natural History) 55: 209-257.

ARNOLD S. (1983). Morphology, performance and fitness. American Zoologist 23: 347-361. https://doi.org/10.1093/icb/23.2.347

Baeckens S., Edwards S., Huyghe K., \& VAn Damme R. (2015). Chemical signalling in lizards: an interspecific comparison of femoral pore numbers in Lacertidae. Biological Journal of the Linnean Society 114 (1): 44-57. https://doi.org/10.1111/bij.12414

BAECKens S., DRIESSEnS T. \& VAN DAmme R. (2016). Intersexual chemo-sensation in a "visuallyoriented" lizard, Anolis sagrei. PeerJ 4: e1874. https://doi.org/10.7717/peerj.1874

Baeckens S., García-Roa R., Martín J. \& VAn Damme R. (2017a). The Role of Diet in Shaping the Chemical Signal Design of Lacertid Lizards. Journal of Chemical Ecology 43 (9): 902-910. https://doi.org/10.1007/s10886-017-0884-2

BAECKENS S., VAN DAMme R. \& COOPER W.E. (2017b). How phylogeny and foraging ecology drive the level of chemosensory exploration in lizards and snakes. Journal of Evolutionary Biology 30 (3): 627-640. https://doi.org/10.1111/jeb.13032

Baeckens S., Herrel A., Broeckhoven C., Vasilopoulou-Kampitsi M., Huyghe K., Goyens J. \& VAN DAMME R. (2017c). Evolutionary morphology of the lizard chemosensory system. Scientific Reports 7: 10141. https://doi.org/10.1038/s41598-017-09415-7 
Baeckens S., Martín J., Garcia-Roa R., Pafilis P., Huyghe K. \& Van Damme R. (2018a). Environmental conditions shape the chemical signal design of lizards. Functional Ecology 32: 566-580. https://doi.org/10.1111/1365-2435.12984

Baeckens S., Martín J., García-RoA R. \& VAn Damme R. (2018b). Sexual selection and the chemical signal design of lacertid lizards. Zoological Journal of the Linnean Society 183 (2): 445-457. https://doi.org/10.1093/zoolinnean/zlx075

BAECKEnS S., Llusia D., Garcia-RoA R. \& MARTÍN J. (2019) Lizard calls convey honest information on body size and bite performance: a role in predator deterrence? Behavioral Ecology and Sociobiology 73: 87. https://doi.org/10.1007/s00265-019-2695-7

BALUŠKA F. (2009). Signaling and Communication in Plants. Springer, New York.

Barbosa D., Font E., Desfilis E. \& Carretero M.A. (2006). Chemically mediated species recognition in closely related Podarcis wall lizards. Journal of Chemical Ecology 32: 1587-1598. https://doi.org/10.1007/s10886-006-9072-5

BARRETT P.H., GAUTREy P.J., HerberT S., KoHN D. \& SMITH S. (1987). Charles Darwin's Notebooks, 1836-1844: Geology, Transmutation of Species, Metaphysical Enquiries. Cambridge University Press, Cambridge.

Barrett R.D.H., Laurent S., Mallarino R., Pfeifer S.P., Xu C.C.Y., Foll M., WaKamatsu K., DuKe-COHAN J.S., JENSEN J.D. \& HOEKSTRA H.E. (2019). Linking a mutation to survival in wild mice. Science 363: 499-504. https://doi.org/10.1126/science.aav3824

BARTH R.H. (1965). Insect mating behavior: endocrine control of a chemical communication system. Science 149: 882-883. https://doi.org/10.1126/science.149.3686.882

Barton R.A., Purvis A., HARVey P.H., Barton R.A., Purvis A. \& HARVEy P.H. (1995). Evolutionary radiation of visual and olfactory brain systems in primates, bats and insectivores. Philosophical Transactions of the Royal Society B 348: 381-392. https://doi.org/10.1098/rstb.1995.0076

BAUwENS D. (1999). Life-history variation in lacertid lizards. Natura Croatica 8: 239-252.

Benson D.A., KARSCh-MizRAChi I., LiPMAN D.J., Ostell J. \& SAYERs E.W. (2009). GenBank. Nucleic Acids Res. 37: 26-31. Available from https://www.ncbi.nlm.nih.gov/genbank/ [accessed 26 June 2019].

Bierl B., Beroza M. \& Collier C.W. (1970). Potent sex attractant of the gypsy moth: its isolation, identification, and synthesis. Science 170: 87-89. https://doi.org/10.1126/science.170.3953.87

BILLEN J. (2006). Signal variety and communication in social insects. Proceedings of the Netherlands Entomology Society Meeting 17: 9-25.

BlomQuist G.J. \& BAGNÈRes A-G. (2010). Insect Hydrocarbons: Biology, Biochemistry and Chemical Ecology. Cambridge University Press, Cambridge.

BoHN K.M., Moss C.F. \& WILKINSON G.S. (2006). Correlated evolution between hearing sensitivity and social calls in bats. Biology Letters 2: 561-564. https://doi.org/10.1098/rsbl.2006.0501

BÖLKER M. \& KAHMANN R. (1993). Sexual pheromones and mating responses in fungi. The Plant Cell 5: 1461-1469. https://doi.org/10.1105/tpc.5.10.1461

BOSSERT W.H. \& WILSON E.O. (1963). The analysis of olfactory communication among animals. Journal of Theoretical Biology 5: 443-469. https://doi.org/10.1016/0022-5193(63)90089-4

BOUGHMAN J.W. (2002). How sensory drive can promote speciation. Trends in Ecology and Evolution 17: 571-577. https://doi.org/10.1016/S0169-5347(02)02595-8

BOWMAKER J.K. (2008). Evolution of vertebrate visual pigments. Vision Research 48: 2022-2041. https://doi.org/10.1016/j.visres.2008.03.025 
Bradbury J.W. \& Vehrencamp S.L. (1998). Principles of Animal Communication. Sinauer Assoc. Inc., Sunderland.

BRANN J.H. \& FADOOL D.A. (2006). Vomeronasal sensory neurons from Sternotherus odoratus (stinkpot/ musk turtle) respond to chemosignals via the phospholipase C system. Journal of Experimental Biology 209: 1914-1927. https://doi.org/10.1242/jeb.02206

Breithaupt T. \& Thiel M. (2011). Chemical Communication in Crustaceans. Springer, New York.

CARAzo P., Font E. \& DesfiLis E. (2007). Chemosensory assessment of rival competitive ability and scent-mark function in a lizard, Podarcis hispanica. Animal Behaviour 74: 895-902. https://doi.org/10.1016/j.anbehav.2007.02.011

CARAzo P., Font E. \& DesfiLis E. (2011). The role of scent marks in female choice of territories and refuges in a lizard (Podarcis hispanica). Journal of Comparative Psychology 125: 362-365. https://doi.org/10.1037/a0023404

CARO S.P., BALTHAZART J. \& BONADONNA F. (2015). The perfume of reproduction in birds: chemosignaling in avian social life. Hormones and Behavior 68: 25-42. https://doi.org/10.1016/j.yhbeh.2014.06.001

CARRETERo M.A. (2004). From set menu to a la carte: linking issues in trophic ecology of Mediterranean lacertids. Italian Journal of Zoology 71: 121-133. https://doi.org/10.1080/11250000409356621

Castilla M.A., VAn Damme R. \& BAuwens D. (1999). Field body temperatures, mechanisms of thermoregulation and evolution of thermal characteristics in lacertid lizards. Natura Croatia 8: 253-257.

Chen I.-P., Stuart-Fox D., Hugall A.F. \& Symonds M.R.E. (2012). Sexual selection and the evolution of complex color patterns in dragon lizards. Evolution 66: 3605-3614. https://doi.org/10.1111/j.1558-5646.2012.01698.x

Cheverud J.M., Dow M.M. \& Luetenegger W. (1985). The quantitative assessment of phylogenetic constraints in comparative analyses: sexual dimorphism in body weight among primates. Evolution 39: 1335-1351. https://doi.org/10.1111/j.1558-5646.1985.tb05699.x

Clutton-Brock T.H. \& Harvey P.H. (1979). Comparison and adaptation. Proceedings of the Royal Society B 205: 547-565. https://doi.org/10.1098/rspb.1979.0084

Clutton-Brock T.H. \& HuChard E. (2013). Social competition and selection in males and females. Philosophical Transactions of the Royal Society B 368:20130074. https://doi.org/10.1098/rstb.2013.0074

COLE C.J. (1966). Femoral glands in lizards: a review. Herpetologica 22: 119-206.

COMForT A. (1971). Likelihood of human pheromones. Nature 230: 432-479.

https://doi.org/10.1038/230432a0

COOPER W.E. (1994). Chemical discrimination by tongue-flicking in lizards: a review with hypotheses on its origin and its ecological and phylogenetic relationships. Journal of Chemical Ecology 20: 439487. https://doi.org/10.1007/BF02064449

COOPER W.E. (1995a). Evolution and function of lingual shape in lizards, with emphasis on elongation, extensibility, and chemical sampling. Journal of Chemical Ecology 21: 477-505.

https://doi.org/10.1007/BF02036744

COOPER W.E. (1995b). Foraging mode, prey chemical discrimination, and phylogeny in lizards. Animal Behaviour 50: 973-985. https://doi.org/10.1016/0003-3472(95)80098-0

COOPER W.E. (1996). Variation and evolution of forked tongues in squamate reptiles. Herpetological Natural History 4: 135-150. 
COOPER W.E. (1997a). Independent evolution of squamate olfaction and vomerolfaction and vomerolfactory evolution correlated with lingual structure. Amphibia-Reptilia 18: 85-105. https://doi.org/10.1163/156853897X00332

COOPER W.E. (1997b). Correlated evolution of prey chemical discrimination with foraging, lingual morphology and vomeronasal chemoreceptor abundance in lizards. Behavioral Ecology and Sociobiology 41: 257-265. https://doi.org/10.1007/s002650050387

COOPER W.E. (2005). The foraging mode controversy: both continuous variation and clustering of foraging movements occur. Journal of Zoology 267 (2): 179-190.

https://doi.org/10.1017/S0952836905007375

COOPER W. \& BURGHARDT G. (1990). Vomerolfaction and vomodor. Journal of Chemical Ecology 16: 103-105. https://doi.org/10.1007/BF01021271

COOPER W.E. \& Lemos-Espinal J.A. (2001). Coordinated ontogeny of food preference and responses to chemical food stimuli by a lizard, Ctenosaura pectinata. Ethology 107: 639-653. https://doi.org/10.1046/j.1439-0310.2001.00690.x

CoOper W.E. \& PÉrez-Mellado V. (2002a). Pheromonal discriminations of sex, reproductive condition, and species by the lacertid lizard Podarcis hispanica. Journal of Experimental Biology 292: 523-527. https://doi.org/10.1002/jez.10089

COOPER W.E. \& PÉREZ-Mellado V. (2002b). Responses to food chemicals by two insectivorous and one omnivorous species of lacertid lizards. Netherlands Journal of Zoology 52: 11-28.

CoOper W.E., Baird T.A., CALdwell J.P. \& VitT L.J. (2003). Pursuit deterrent signalling by the Bonaire whiptail lizard Cnemidophorus murinus. Behaviour 141: 297-311.

https://doi.org/10.1163/156853904322981860

CoOper N., Thomas G.H. \& FitzJohn R.G. (2016). Shedding light on the "dark side" of phylogenetic comparative methods. Methods in Ecology and Evolution 7: 693-699.

https://doi.org//10.1111/2041-210X.12533

Daghfous G., Smargiassi M., Libourel P.A., Wattiez R. \& Bels V. (2012). The function of oscillatory tongue-flicks in snakes: insights from kinematics of tongue-flicking in the banded water snake (Nerodia fasciata). Chemical Senses 37: 883-896. https://doi.org/10.1093/chemse/bjs072

DARWIN C.R. (1859). On the Origin of Species by Means of Natural Selection, or the Preservation of Favoured Races in the Struggle for Life. John Murray, London.

DARWIN C.R. (1871). The Descent of Man and Selection in Relation to Sex. John Murray, London.

DARWIN C.R. (1872). The Expression of the Emotions in Man and Animals. John Murray, London.

DE Villiers A., Flemming A. \& Mouton P. LE F.N. (2015). Generation glands of cordylid lizards: mechanism of secretion transfer to the environment. Amphibia-Reptilia 36: 351-360.

https://doi.org/10.1163/15685381-00003011

DíAZ J.A. (1995). Prey selection by lacertid lizards: a short review. Herpetological Journal 5: 245-251.

DiAZ-URIARTE R. \& GARLAND T. (1996). Testing hypotheses of correlated evolution using phylogenetically independent contrasts: sensitivity to deviations from Brownian motion. Systematic Biology 45: 27-47. https://doi.org/10.1093/sysbio/45.1.27

DOOLING R., \& FAY R. (2000). Comparative hearing: birds and reptiles. In: FAY R.R. \& POPPER A.N (eds) Springer Handbook of Auditory Research: 1-380. Springer, New York.

Driessens T., Baeckens S., Balzarolo M., Vanhooydonck B., Huyghe K. \& Van Damme R. (2017). Climate-related environmental variation in a visual signalling device: the male and female dewlap in Anolis sagrei. Journal of Evolutionary Biology 30: 1846-1861. https://doi.org/10.1111/jeb.13144 
Duvall D. (1979). Western fence lizard (Sceloporus occidentalis): chemical signals, conspecific discriminations and release of a species-typical visual display. Journal of Experimental Zoology 210: 321-326. https://doi.org/10.1002/jez.1402100215

EBLING F.J.G. (1988). Scent glands in mammals: social functions and implications of apocrine gland odours. Journal of Applied Cosmetology 6: 1-14.

Elias D.O., MASON A.C., MAdDISON W.P. \& Hoy R.R. (2003). Seismic signals in a courting male jumping spider (Araneae: Salticidae). Journal of Experimental Biology 206: 4029-4039.

https://doi.org/10.1242/jeb.00634

EISENBERG J.F. \& KLEIMAN D.G. (1972). Olfactory communication in mammals. Annual Review of Ecology and Systematics 3: 1-32. https://doi.org/10.1146/annurev.es.03.110172.000245

EISNER T. \& Berenbaum M. (2002). Chemical ecology: missed opportunities? Science 295: 5562. https://doi.org/10.1126/science.295.5562.1973

EISTHEN H.L. (1992). Phylogeny of the vomeronasal system and of receptor cell types in the olfactory and vomeronasal epithelia of vertebrates. Microscopy Research \& Technique 23: 1-21.

https://doi.org/10.1002/jemt.1070230102

EISTHEN H.L. (1997). Evolution of vertebrate olfactory systems. Brain, Behavior and Evolution 50: 222-233. https://doi.org/10.1159/000113336

EISTHEN H.L. \& WyATT T.D. (2006). The vomeronasal system and pheromones. Current Biology 16: 1-3. https://doi.org/10.1016/j.cub.2006.01.038

ENDLER J.A. (1992). Signals, signal conditions, and the direction of evolution. The American Naturalist 139: 125-153. https://doi.org/10.1086/285308

ENDLER J.A. (1993). Some general comments on the evolution and design of animal communication systems. Philosophical Transactions of the Royal Society B 340: 215-225.

https://doi.org/10.1098/rstb.1993.0060

ENDLER J.A. \& BASOLO A.L. (1998). Sensory ecology, receiver biases and sexual selection. Trends in Ecology and Evolution 13: 415-420. https://doi.org/10.1016/S0169-5347(98)01471-2

ERDTMANN L. \& AMÉZQUiTA A. (2009). Differential evolution of advertisement call traits in dart-poison frogs (Anura: Dendrobatidae). Ethology 115: 801-811.https://doi.org/10.1111/j.1439-0310.2009.01673.x ESPMARK Y., AMUndSEn T. \& RosenQvist G. (2000). Animal Signals: Signalling and Signal Design in Animal Communication. Tapir Academic Press, Trondheim.

FELSENSTEIN J. (1985). Phylogenies and the comparative method. The American Naturalist 125: 3-147. https://doi.org/10.1086/284325

FELSENSTEIN J. (2004). Inferring Phylogenies. Sinauer Associates, Sunderland.

FERNANDEZ A.A. \& MORRIS M.R. (2007). Sexual selection and trichromatic color vision in primates: statistical support for the preexisting-bias hypothesis. The American Naturalist 170: 10-20. https://doi.org/10.1086/518566

FILORAMO N.I. \& SCHWENK K. (2009). The mechanism of chemical delivery to the vomeronasal organs in squamate reptiles: a comparative morphological approach. Journal of Experimental Zoology 34: 2034. https://doi.org/10.1002/jez.492

Fögen T. (2014). Animal communication. In: CAMPBell G.L. (ed.) The Oxford Handbook of Animals in Classical Thought and Life: 216-232. Oxford University Press, Oxford. 
Font E., BARbosa D., SAMPEDRo C. \& CARAZO P. (2012a). Social behavior, chemical communication, and adult neurogenesis: studies of scent mark function in Podarcis wall lizards. General and Comparative Endocrinology 177: 9-17. https://doi.org/10.1016/j.ygcen.2012.02.015

Font E., Carazo P., Pérez i de Lanuza G. \& Kramer M. (2012b). Predator-elicited foot shakes in wall lizards (Podarcis muralis): evidence for a pursuit-deterrent function. Journal of Comparative Psychology (126): 87-96. https://doi.org/10.1037/a0025446

FRAENKEL G.S. (1959). The raison d'être of substances of secondary plant. Science 129: 1466-1470. https://doi.org/10.1126/science.129.3361.1466

Frankenberg E. \& Werner Y.L. (1991). Vocal communication in the Reptilia: facts and questions. Acta Zoologica 41: 45-62.

GABIROT M., CASTILlA A.M., LÓPEZ P. \& MARTín J. (2010a). Chemosensory species recognition may reduce the frequency of hybridization between native and introduced lizards. Canadian Journal of Zoology 88: 73-80. https://doi.org/10.1139/Z09-120

GABIROT M., CASTILLAA.M., LÓPEZP. \& MARTÍN J. (2010b). Differences in chemical signals may explain species recognition between an island lizard Podarcis atrata, and related mainland lizards $P$. hispanica. Biochemical Systematics and Ecology 38: 521-528. https://doi.org/10.1016/j.bse.2010.05.008

GABIROT M. LÓPEZ P. \& MARTín J. (2013). Female mate choice based on pheromone content may inhibit reproductive isolation between distinct populations of Iberian wall lizards. Current Zoology 59: 210-220. https://doi.org/10.1093/czoolo/59.2.210

Gabirot M., Raux L., Dell'Ariccia G., Bried J., Ramos R., Gonález-Solís J., Buatois B., CROCHET P.A. \& BONADONNA F. (2016). Chemical labels differ between two closely related shearwater taxa. Journal of Avian Biology 47: 540-551. https://doi.org/10.1111/jav.00853

GARCÍA-RoA R., JARA M., BAECKENS S., LÓPEZP., VAN DAMME R., MARTíN J. \& PinCHEIRA-DONOSO D. (2017). Macroevolutionary diversification of glands for chemical communication in squamate reptiles. Scientific Reports 7: 9288. https://doi.org/10.1038/s41598-017-09083-7

Gauthier J.A, Kearney M., Maisano J.A., Rieppel O. \& BehlKe A.D.B. (2012). Assembling the Squamate Tree of Life: perspectives from the phenotype and the fossil record. Bulletin of the Peabody Museum of Natural History 53: 3-308. https://doi.org/10.3374/014.053.0101

Garamszegi L.Z. (2014). Modern Phylogenetic Comparative Methods and their Application in Evolutionary Biology: Concepts and Practice. Springer, Heidelberg.

GARAMSZEgi L.Z., Eens M., ERRITZøE J. \& Møller A.P. (2005). Sexually size dimorphic brains and song complexity in passerine birds. Behavioral Ecology 16: 335-345. https://doi.org/10.1093/beheco/arh167

GARCÍA-MUÑOZ E. \& SiLLERO N. (2010). Two new types of noose for capturing herps. Acta Herpetologica 5: 259-263. https://doi.org/10.13128/Acta_Herpetol-9033

Garland T., Harvey P. \& IVES A. (1992). Procedures for the analysis of comparative data using phylogenetically independent contrasts. Systematic Biology 41: 18-32.

https://doi.org/10.1093/sysbio/41.1.18

GiLlies M. (1980). The role of carbon dioxide in host-finding by mosquitoes (Diptera: Culicidae): a review. Bulletin of Entomological Research 70: 525-532. https://doi.org/10.1017/S0007485300007811

GitTLEMAN J.L. (1991). Carnivore olfactory bulb size: allometry, phylogeny and ecology. Journal of Zoology 225: 253-272. https://doi.org/10.1111/j.1469-7998.1991.tb03815.x

GoOLSBY E.W. (2015). Phylogenetic comparative methods for evaluating the evolutionary history of function-valued traits. Systematic Biology 64: 568-578. https://doi.org/10.1093/sysbio/syv012 
Gould S. \& Lewontin R. (1979). The spandrels of San Marco and the Panglossian paradigm: a critique of the adaptionist programme. Proceedings of the Royal Society B 205: 581-598. https://doi.org/10.1098/rspb.1979.0086

GRAFEN A. (1990). Biological signals as handicaps. Journal of Theoretical Biology 144: 517-546. https://doi.org/10.1016/S0022-5193(05)80088-8

GUILFORD T. \& DAWKINS M.S. (1991). Receiver psychology and the evolution of animal signals. Animal Behaviour (42): 1-14. https://doi.org/10.1016/S0003-3472(05)80600-1

GUILFORD T. \& DAWKINS M.S. (1993). Receiver psychology and the design of animal signals. Trends in Neurosciences 16: 430-436. https://doi.org/10.1016/0166-2236(93)90068-W

HALPERN M. (1987). The organization and function of the vomeronasal system. Annual Review of Neuroscience 10: 325-362. https://doi.org/10.1146/annurev.ne.10.030187.001545

HALPERN M. (1992). Nasal chemical senses in reptiles: structure and function. In: GANS C. \& CREWS D. (eds) Biology of the Reptilia. Volume 18, Physiology E: 424-532. University of Chicago, Chicago.

HALPERN M. \& MARTínEZ-MARCOS A. (2003). Structure and function of the vomeronasal system: an update. Progress in Neurobiology 70: 245-318. https://doi.org/10.1016/S0301-0082(03)00103-5

HARMON L.J. (2018). Phylogenetic Comparative Methods: Learning from Trees. CreateSpace Independent Publishing Platform.

HARRINGTON F.H. \& MECH L.D. (1979). Wolf howling and its role in territory maintenance. Behaviour 68 (3-4): 207-249. https://doi.org/10.1163/156853979X00322

Harris D.J., CARranZa S., Arnold E.N., Pinho C. \& FerRand N. (2002). Complex biogeographical distribution of genetic variation within Podarcis wall lizards across the Strait of Gibraltar. Journal of Biogeography 29: 1257-1262. https://doi.org/10.1046/j.1365-2699.2002.00744.x

HARTMANN T. (2008). The lost origin of chemical ecology in the late 19th century. Proceedings of the National Academy of Sciences 105: 4541-4546. https://doi.org/10.1073/pnas.0709231105

HaRvey P.H. \& Pagel M.D. (1991). The Comparative Method in Evolutionary Biology. Oxford University Press, Oxford.

HARVEY P.H. \& PURVIS A. (1991). Comparative methods for explaining adaptations. Nature 351: 619624. https://doi.org/10.1038/351619a0

Harvey S., Jemiolo B. \& Novotny M. (1989). Pattern of volatile compounds in dominant and subordinate male mouse urine. Journal of Chemical Ecology 15: 2061-2072.

https://doi.org/10.1007/BF01207438

HeBETS E.A. \& PAPAJ D.R. (2005). Complex signal function: developing a framework of testable hypotheses. Behavioral Ecology and Sociobiology 57: 197-214.

https://doi.org/10.1007/s00265-004-0865-7

Herrel A., Van Damme R., Vanhooydonck B. \& De Vree F. (2001). The implications of bite performance for diet in two species of lacertid lizards. Canadian Journal of Zoology 670: 662-670. https://doi.org/10.1139/cjz-79-4-662

Herrel A., VAnhoOydonck B. \& VAn DAmme R. (2004). Omnivory in lacertid lizards: adaptive evolution or constraint? Journal of Evolutionary Biology 17: 974-984.

https://doi.org/10.1111/j.1420-9101.2004.00758.x

Herrel A., Schaerlaeken V., Meyers J.J., Metzger K.A. \& Ross C.F. (2007a). The evolution of cranial design and performance in squamates: consequences of skull-bone reduction on feeding behavior. Integrative and Comparative Biology 47: 107-117. https://doi.org/10.1093/icb/icm014 
Herrel A., JAmeS R.S. \& VAN DAMme R. (2007b). Fight versus flight: physiological basis for temperature-dependent behavioral shifts in lizards. Journal of Experimental Biology 210: 1762-1767. https://doi.org/10.1242/jeb.003426

HiLDEBRAND J.G. \& SHEPHERD G.M. (1997). Mechanisms of olfactory discrimination: converging evidence for common principles across phyla. Annual Review of Neurosciences 20: 595-631. https://doi.org/10.1146/annurev.neuro.20.1.595

HUELSENBECK J.P. \& BOLLBACK J.P. (2001). Empirical and hierarchical Bayesian estimation of ancestral states. Systematic Biology 50: 351-366. https://doi.org/10.1080/106351501300317978

HuELSENBECK J.P., RANNALA B. \& MASLY J.P. (2000). Accommodating phylogenetic uncertainty in evolutionary studies. Science 288: 2349-50. https://doi.org/10.1126/science.288.5475.2349

HuEY R.B. \& PIANKA E.R. (1977). Natural selection for juvenile lizards mimicking noxious beetles. Science 195: 201-203. https://doi.org/10.1126/science.831272

HUEY R.B. \& PIANKA E.R. (1981). Ecological consequences of foraging mode. Ecology 62: 991-999. https://doi.org/10.2307/1936998

Hughes N.K., Kelley J.L., BANKS P.B. \& Grether G. (2012). Dangerous liaisons: the predation risks of receiving social signals. Ecology Letters 15: 1326-1339.

https://doi.org/10.1111/j.1461-0248.2012.01856.x

Hunt J., Snook R.R., Mitchell C., Crudgington H.S. \& Moore A.J. (2012). Sexual selection and experimental evolution of chemical signals in Drosophila pseudoobscura. Journal of Evolutionary Biology 25: 2232-2241. https://doi.org/10.1111/j.1420-9101.2012.02603.x

Huyghe K., Vanhooydonck B., Herrel A., Tadic Z. \& Van Damme R. (2007). Morphology, performance, behavior and ecology of three color morphs in males of the lizard Podarcis melisellensis. Integrative and Comparative Biology 47: 211-20. https://doi.org/10.1093/icb/icm043

IBÁÑEZ A., MARZAL A., LÓPEZ P. \& MARTín J. (2014). Chemosensory assessment of rival body size is based on chemosignal concentration in male Spanish terrapins. Behavioral Ecology Sociobiology 68: 2005-2012. https://doi.org/10.1007/s00265-014-1806-8

IRSCHICK D.J. \& LOSOS J.B. (1998). A comparative analysis of the ecological significance of maximal locomotor performance in Caribbean Anolis lizards. Evolution 52: 219-226.

https://doi.org/10.2307/2410937

JACOBSON M., REDFERn R.E., JONES W.A. \& ALDRIDGE M.H. (1970). Sex pheromones of the southern armyworm moth: isolation, identification, and synthesis. Science 170: 542-544.

https://doi.org/10.1126/science.170.3957.542

JOHNSTONE R.A. (2000). Conflicts of interest in signal evolution. In: ESPMARK Y., AMUNDSEN T. \& RosenQvist G. (eds) Animal Signals: Signalling and Signal Design in Animal Communication: 465485. Tapir Academic Press, Trondheim.

KAUPP U.B. (2010). Olfactory signalling in vertebrates and insects: differences and commonalities. Nature Reviews Neuroscience 11: 188-200. https://doi.org/10.1038/nrn2789

KEVERNE E.B. (1999). The vomeronasal organ. Science 286: 716.

https://doi.org/10.1126/science.286.5440.716

Khannoon E.R., Breithaupt T., El-Gendy A. \& Hardege J.D. (2010). Sexual differences in behavioral response to femoral gland pheromones of Acanthodactylus boskianus. Herpetological Journal 20: 225-229. 
KhanNoOn E.R., El-Gendy A. \& HARDEGE J.D. (2011). Scent marking pheromones in lizards: cholesterol and long chain alcohols elicit avoidance and aggression in male Acanthodactylus boskianus (Squamata: Lacertidae). Chemoecology 21: 14-149. https://doi.org/10.1007/s00049-011-0076-4

KIKUCHI D.W. \& PfENNIG D.W. (2010). Predator cognition permits imperfect coral snake mimicry. The American Naturalist 176: 830-834. https://doi.org/10.1086/657041

Kikuyama S., Toyoda F., OhmiYa Y., Matsuda K., TANaka S. \& Hayashi H. (1995). Sodefrin: a female-attracting peptide pheromone in newt cloacal glands. Science 267: 1643-1645. https://doi.org/10.1126/science.7886452

Kopena R., Martín J., LóPez P. \& Herczeg G. (2011). Vitamin E supplementation increases the attractiveness of males' scent for female European green lizards. PloS ONE 6: e19410. https://doi.org/10.1371/journal.pone.0019410

KOPENA R., LÓPEZ P. \& MARTíN J. (2014). Relative contribution of dietary carotenoids and vitamin E to visual and chemical sexual signals of male Iberian green lizards: an experimental test. Behavioral Ecology and Sociobiology 68: 571-581. https://doi.org/10.1007/s00265-013-1672-9

KRIEGER J. \& BREER H. (1999). Olfactory reception in invertebrates. Science 286: 720-723. https://doi.org/10.1126/science.286.5440.720

Labra A., Silva G., Norambuena F., Velásquez N. \& Penna M. (2013). Acoustic features of the weeping lizard's distress call. Copeia: 206-212. https://doi.org/10.1643/CE-12-026

Lapiedra O., Schoener T.W., Leal M., Losos J.B., \& Kolbe J.J. (2018). Predator-driven natural selection on risk-taking behavior in anole lizards. Science 1020: 1017-1020.

https://doi.org/10.1126/science.aap9289

LaziĆ M.M., CARretero M.A., Crnobrnja-Isailović J. \& Kaliontzopoulou A. (2015). Effects of environmental disturbance on phenotypic variation: an integrated assessment of canalization, developmental stability, modularity, and allometry in lizard head shape. The American Naturalist 185: 44-58. https://doi.org/10.1086/679011

LEMASTER M.P. \& MASON R.T. (2001). Evidence for a female sex pheromone mediating male trailing behavior in the red-sided garter snake, Thamnophis sirtalis parietalis. Chemoecology 11: 149-152. https://doi.org/10.1007/PL00001845

LÓPEZ P. \& MARTíN J. (2002). Chemical rival recognition decreases aggression levels in male Iberian wall lizards, Podarcis hispanica. Behavioral Ecology and Sociobiology 51: 461-465.

https://doi.org/10.1007/s00265-001-0447-x

Losos J.B. \& MiLES D.B. (1994). Adaptation, constraint, and the comparative method: phylogenetic issues and methods. In: WAINWRIGHT P.C. \& REILlY S. (eds) Ecological Morphology: Integrative Organismal Biology: 60-98. University of Chicago Press, Chicago.

Losos J.B. \& RicKLEFS R.E. (2009). Adaptation and diversification on islands. Nature 457: 830-836. https://doi.org/10.1038/nature07893

Losos J.B., Jackman T.R., LARson A., DE QueIroz K. \& Rodriguez-Schettino L. (1998). Contingency and determinism in replicated adaptive radiations of island lizards. Science (79) 21152118. https://doi.org/10.1126/science.279.5359.2115

Losos J.B., Hillis D.M. \& GREENE H.W. (2012). Who speaks with a forked tongue ? Science 338: 1428-1429. https://doi.org/10.1126/science.1232455

LUCAS C. (1944). Excretions, ecology and evolution. Nature 25: 378-379.

https://doi.org/10.1038/153378b0 
MacDonald D.W., Müller-Schwarze D. \& NatynczuK S.E. (1990). Chemical Signals in Vertebrates 5. Oxford University Press, Oxford.

Maex M., Van Bocxlaer I., Mortier A., Proost P. \& Bossuyt F. (2016). Courtship pheromone use in a model urodele, the Mexican axolotl (Ambystoma mexicanum). Scientific Reports 6: 20184. https://doi.org/10.1038/srep20184

MADDISON W.P., MidFORD P.E. \& OTTO S.P. (2007). Estimating a binary character's effect on speciation and extinction. Systematic Biology 56: 701-10. https://doi.org/10.1080/10635150701607033

MADISON D.M. (1977). Chemical communication in amphibians and reptiles. In: MÜLLER-SCHWARZE D. \& Mozell M.M. (eds) Chemical Signals in Vertebrates. Volume 1: 135-168. Plenum, New York.

MAngiacotti M., Gaggiani S., COlAdonato A.J., SCAli S., Zuffi M.A.L. \& SACChi R. (2019). First experimental evidence that proteins from femoral glands convey identity-related information in a lizard. Acta Ethologica 22: 57-65. https://doi.org/10.1007/s10211-018-00307-1

MARTín J. \& LÓPEZ P. (2012). Supplementation of male pheromone on rock substrates attracts female rock lizards to the territories of males: a field experiment. PloS ONE 7: e30108.

https://doi.org/10.1371/journal.pone.0030108

MARTín J. \& LÓPEZ P. (2013). Responses of female rock lizards to multiple scent marks of males: effects of male age, male density and scent over-marking. Behavioral Processes 94: 109-114. https://doi.org/10.1016/j.beproc.2013.01.002

MARTÍN J. \& LÓPEZ P. (2014). Pheromones and chemical communication in lizards. In: RHEUBERT J.L., Siegen D.S. \& TRAUth S.E. (eds) The Reproductive Biology and Phylogeny of Lizards and Tuatara: 43-77. Academic Press, Boca Raton.

MARTíN J. \& LÓPEZ P. (2015). Condition-dependent chemosignals in reproductive behavior of lizards. Hormones and Behavior 68: 14-24. https://doi.org/10.1016/j.yhbeh.2014.06.009

MARTín J., ORTEGA J. \& LÓPEZ P. (2015). Experience may allow increasing accuracy of the innate chemosensory recognition of snake predators by Iberian wall lizards. Behavioral Ecology and Sociobiology 69: 1565-1572. https://doi.org/10.1007/s00265-015-1968-z

Martin M., Meylan S., Perret S. \& Le Galliard J.F. (2015). UV coloration influences spatial dominance but not agonistic behaviors in male wall lizards. Behavioral Ecology and Sociobiology 69: 1483-1491. https://doi.org/10.1007/s00265-015-1960-7

MASON R.T. (1992). Reptilian pheromones. In: GANS C. \& CREws D. (eds) Biology of the Reptilia, Volume 18, Physiology E: Hormones, Brain, and Behavior: 114-228. University of Chicago Press, Chicago

MASON M.J. \& NARINS P.M. (2002). Seismic sensitivity in the desert golden mole (Eremitalpa granti): a review. Journal of Comparative Psychology 116: 158-163. https://doi.org/10.1037/0735-7036.116.2.158

MASON R.T. \& PARKER M.R. (2010). Social behavior and pheromonal communication in reptiles. Journal of Comparative Physiology 196: 729-49. https://doi.org/10.1007/s00359-010-0551-3

Mason R.T., Fales H.M., Jones T.H., PANnell L.K., Chinn J.W. \& CreWs D. (1989). Sex pheromones in snakes. Science 245: 290-293. https://doi.org/10.1126/science.2749261

MAYERL C., BAECKENS S. \& VAN DAMME R. (2015). Evolution and role of the follicular epidermal gland system in non-ophidian squamates. Amphibia-Reptilia 36: 185-206.

https://doi.org/10.1163/15685381-00002995

MAYNARD-SMith J. \& HARPER D. (2003). Animal Signals. Oxford University Press, New York.

MEIRI S. (2007). Size evolution in island lizards. Global Ecology and Biogeography 16: 702-708. https://doi.org/10.1111/j.1466-8238.2007.00327.x 
Mesquita D.O., Costa G.C., Colli G.R., Costa T.B., ShePard D.B., VitT L.J. \& Pianka E.R. (2016a). Life-history patterns of lizards of the world. The American Naturalist 187: 689-705. https://doi.org/10.1086/686055

Mesquita D.O., Faria R.G., Colli G.R., VitT L.J. \& Pianka E.R. (2016b). Lizard life-history strategies. Austral Ecology 41: 1-5. https://doi.org/10.1111/aec.12276

MiLES D.B. (1993). Historical perspectives in ecology and evolutionary biology: the use of phylogenetic comparative analyses. Annual Review of Ecology and Systematics 24: 587-619.

https://doi.org/10.1146/annurev.ecolsys.24.1.587

Miller J.R., BAKer T.C., CARDE R.T. \& RoelofS W.L. (1976). Reinvestigation of oak leaf roller sex pheromone components and the hypothesis that they vary with diet. Science 192: 140-143. https://doi.org/10.1126/science.1257758

MonteAlegre-Z F. (2009). Scale effects and constraints for sound production in katydids (Orthoptera: Tettigoniidae): correlated evolution between morphology and signal parameters. Journal of Evolutionary Biology 22: 355-366. https://doi.org/10.1111/j.1420-9101.2008.01652.x

MORALES B. \& BACIGALUPO J. (1996). Chemical reception in vertebrate olfaction: evidence for multiple transduction pathways. Biological Research 29: 333-341.

MoulTon D. (1968). Communication by chemical signals. Science 162: 1176-1180.

https://doi.org/10.1126/science.162.3858.1176

Müller-Schwarze D. (2006). Chemical Signals in Vertebrates. Cambridge University Press, Cambridge.

Müller-Schwarze D. \& Silverstein R.M. (1980). Chemical Signals: Vertebrates and Aquatic Invertebrates. Plenum Press, New York.

MYKYTOWICZ R. \& GoODRICH B.S. (1974). Skin glands as organs of communication in mammals. The Journal of Investigative Dermatology 62: 124-131. https://doi.org/10.1111/1523-1747.ep12676776

NeE S., MAY R.M. \& Harvey P.H. (1994). The reconstructed evolutionary process. Philosophical Transactions of the Royal Society B 344: 305-311. https://doi.org/10.1098/Rstb.1994.0068

Nicholson K.E., HARMON L.J. \& LOSOS J.B. (2007). Evolution of Anolis lizard dewlap diversity. PLoS ONE 2: 1-12. https://doi.org/10.1371/journal.pone.0000274

Novosolov M., Rodda G.H., Feldman A., Kadison A.E., Dor R. \& Meiri S. (2016). Power in numbers: the evolutionary drivers of high population density in insular lizards. Global Ecology and Biogeography 25: 87-95. https://doi.org/10.1111/geb.12390

O'CONNELL-ROdwell C.E. (2007). Keeping an "ear" to the ground: seismic communication in elephants. Physiology 22: 287-294. https://doi.org/10.1152/physiol.00008.2007

O'MEARA B.C. (2012). Evolutionary inferences from phylogenies: a review of methods. Annual Review of Ecology, Evolution and Systematics 43: 267-285.

https://doi.org/10.1146/annurev-ecolsys-110411-160331

O’Meara B.C., Graham K.L., Pellis S.M. \& Burghardt G.M. (2015). Evolutionary models for the retention of adult-adult social play in primates: the roles of diet and other factors associated with resource acquisition. Adaptive Behavior 23: 381-391. https://doi.org/10.1177/1059712315611733

ORD T.J. \& MARTINS E.P. (2006). Tracing the origins of signal diversity in anole lizards: phylogenetic approaches to inferring the evolution of complex behaviour. Animal Behaviour 71: 1411-1429. https://doi.org/10.1016/j.anbehav.2005.12.003 
PAfilis P., Foufopoulos J., PoulaKakis N., Lymberakis P. \& VAlakos E.D. (2009). Tail shedding in island lizards (Lacertidae, Reptilia): decline of antipredator defenses in relaxed predation environments. Evolution 63: 1262-1278. https://doi.org/10.1111/j.1558-5646.2009.00635.x

Pagel M. (2014). Foreword. In: Garamszegi L.Z. (ed.) Modern Phylogenetic Comparative Methods and their Application in Evolutionary Biology: Concepts and Practice: vii-viii. Springer, Heidelberg.

Pagel M., MeAde A. \& BARKer D. (2004). Bayesian estimation of ancestral character states on phylogenies. Systematic Biology 53: 673-684. https://doi.org/10.1080/10635150490522232

PARTAN S.R. \& MARLER P. (1999). Communication goes multimodal. Science 283: 1272-1273. https://doi.org/10.1126/science.283.5406.1272

PEAKE T.M. (2005). Eavesdropping in communication networks. In: MCGREGOR P.K. (ed.) Animal Communication Networks: 13-37. Cambridge University Press, Cambridge.

PÉREZ I DE LANUZA G. \& FONT E. (2010). Lizard blues: blue body colouration and ultraviolet polychromatism in lacertids. Revista Española de Herpetología 24: 67-84.

PÉREZ I DE LANUZA G. \& FONT E. (2014). Ultraviolet vision in lacertid lizards: evidence from retinal structure, eye transmittance, SWS1 visual pigment genes and behaviour. Journal of Experimental Biology 217: 2899-909. https://doi.org/10.1242/jeb.104281

PÉREZ I DE LANUZA G. \& FONT E. (2015). Differences in conspicuousness between alternative color morphs in a polychromatic lizard. Behavioral Ecology 26: 1432-1446.

https://doi.org/10.1093/beheco/arv075

PÉREZ I DE LANUZA G. \& FONT E. (2016). The evolution of colour pattern complexity: selection for conspicuousness favours contrasting within-body colour combinations in lizards. Journal of Evolutionary Biology 29: 942-951. https://doi.org/10.1111/jeb.12835

PÉreZ I DE LANUZA G., FonT E. \& MONTERDE J.L. (2013). Using visual modelling to study the evolution of lizard coloration: sexual selection drives the evolution of sexual dichromatism in lacertids. Journal of Evolutionary Biology 26: 1826-1835. https://doi.org/10.1111/jeb.12185

PÉrez-Mellado V. \& Traveset A. (1999). Relationships between plants and Mediterranean lizards. Natura Croatia 8: 275-285.

PERRY G. (1999). The evolution of search modes: ecological versus phylogenetic perspectives. The American Naturalist 153: 98-109. https://doi.org/10.1086/303145

Perry G., LAmpl I., Lerner A., Rothenstein D., Shani E. \& Sivan N. (1990). Foraging mode in lacertid lizards: variation and correlates. Amphibia-Reptilia 11: 373-384.

https://doi.org/10.1163/156853890X00069

PIANKA E.R. (1971). Lizard species density in the Kalahari desert. Ecology 53: 1024-1029. https://doi.org/10.2307/1933808

PiANKA E.R. (1994). The Lizard Man Speaks. University of Texas Press, Austin.

Pincheira-Donoso D., Hodgson D.J. \& Tregenza T. (2008). Comparative evidence for strong phylogenetic inertia in precloacal signalling glands in a species-rich lizard clade. Evolutionary Ecology Research 10: 11-28.

POMIANKOWSKI A. (1988). The evolution of female mating preferences for male genetic quality. In: HARVEY P.H. \& PARTRIDGe L. (eds) Oxford Surveys in Evolutionary Biology: 136-184. Oxford University Press, New York. 
Raina A.K., Jaffe H., Kempe T.G., Keim P., Blacher R.W., Fales H.M., Riley C.T., Klun J.A., RIDGEWAY R.L. \& HAYES D.K. (1989). Identification of a neuropeptide hormone that regulates sex pheromone production in female moths. Science 244: 796-798.

https://doi.org/10.1126/science.244.4906.796

REGNIER F.E. \& LAW, J.H. (1968). Insect pheromones. Journal of Lipid Research 9: 541-551.

REGNIER F.E. \& WILSON E. (1971). Chemical communication and "propaganda" in slave-maker ants. Science 172: 267-269. https://doi.org/10.1126/science.172.3980.267

ReVell L.J., HaRmon L. \& Collar D. (2008). Phylogenetic signal, evolutionary process, and rate. Systematic Biology 57: 591-601. https://doi.org/10.1080/10635150802302427

Ronacher B., Wohlgemuth S., Vogel A. \& Krahe R. (2008). Discrimination of acoustic communication signals by grasshoppers (Chorthippus biguttulus): temporal resolution, temporal integration, and the impact of intrinsic noise. Journal of Comparative Psychology 122: 252-63. https://doi.org/10.1037/0735-7036.122.3.252

RowE C. (1999). Receiver psychology and the evolution of multicomponent signals. Animal Behavior 58: 921-931. https://doi.org/10.1006/anbe.1999.1242

ROWE C. \& GUILFORD T. (1996). Hidden colour aversions in domestic chicks triggered by pyrazine odours of insect warning displays. Nature 383: 520-522. https://doi.org/10.1038/383520a0

RYAN M.J. \& RAND A.S. (1995). Female responses to ancestral advertisement calls in tungara frogs. Science 269: 390-392. https://doi.org/10.1126/science.269.5222.390

RYAN M.J., FOX J., WILCZYNSKI W. \& RAND A. (1990). Sexual selection for sensory exploitation in the frog Physalaemus pustulosus. Nature 343: 66-67. https://doi.org/10.1038/343066a0

Sayers E.W., Barrett T., Benson D.A., Bryant S.H., Canese K., Chetvernin V., Church D.M., DiCuccio M., Edgar R., Feolo S.F.M., Geer L.Y., Helmberg W., Kapustin Y., Landsman D., Lipman D.J., Madden T.L., Maglott D.R., Miller V., Mizrachi I., Ostell J., PruitT K.D., Schuler G.D., Sequeira E., Sherry S.T., Shumway M., Sirotkin K., Souvorov A., Starchenko G., TAtusova T.A., WAgner L., YASChENKo E. \& Ye J. (2009). Database resources of the National Center for Biotechnology Information. Nucleic Acids Research 37: 5-15.

https://doi.org/10.1093/nar/gkn741

SCHEERS H. \& VAN DAMme R. (2002). Micro-scale differences in thermal habitat quality and a possible case of evolutionary flexibility in the thermal physiology of lacertid lizards. Oecologia 132: 323-331. https://doi.org/10.1007/s00442-002-0970-0

Schluessel V., BennetT M.B., Bleckmann H., Blomberg S. \& Collin S.P. (2008). Morphometric and ultrastructural comparison of the olfactory system in elasmobranchs: the significance of structurefunction relationships based on phylogeny and ecology. Journal of Morphology 269: 1365-1386. https://doi.org/10.1002/jmor.10661

SCHNitZler H.U., Moss C.F. \& DeNZINGER A. (2003). From spatial orientation to food acquisition in echolocating bats. Trends in Ecology and Evolution 18: 386-394.

https://doi.org/10.1016/S0169-5347(03)00185-X

SCHOLES E. (2008). Evolution of the courtship phenotype in the bird of paradise genus Parotia (Aves: Paradisaeidae): homology, phylogeny, and modularity. Biological Journal of the Linnean Society 94: 491-504. https://doi.org/10.1111/j.1095-8312.2008.01012.x

Schulz S. (2005). Topics in Current Chemistry, Volume 240: The Chemistry of Pheromones and other Semiochemicals II. Springer, New York. 
SCHWENK K. (1993). The evolution of chemoreception in squamate reptiles: a phylogenetic approach. Brain, Behavior and Evolution 41: 124-137. https://doi.org/10.1159/000113830

SCHWENK K. (1994a). Why snakes have forked tongues. Science 263: 1573-1577. https://doi.org/10.1126/science.263.5153.1573

SCHWENK K. (1994b). Comparative biology and the importance of cladistic classification: a case study from the sensory biology of squamate reptiles. Biological Journal of the Linnean Society 52: 69-82. https://doi.org/10.1006/bijl.1994.1039

SCHWENK K. (1995). Of tongues and noses: chemoreception in lizards and snakes. Trends in Ecology and Evolution 10: 7-12. https://doi.org/10.1016/S0169-5347(00)88953-3

SHINE R. (1980). "Costs” of reproduction in reptiles. Oecologia 46: 92-100. https://doi.org/10.1007/BF00346972

SiH A. \& GLEESON S.K. (1995). A limits-oriented approach to evolutionary ecology. Trends in Ecology and Evolution 10: 378-382. https://doi.org/10.1016/S0169-5347(00)89142-9

Simões B.F., SAmpaio F.L., Jared C., ANTONiaZZi M.M., Loew E.R., BOWMAKER J.K., RodRiguez A., Hart N.S., HunT D.M., PATridge J.C. \& Gower D.J. (2015). Visual system evolution and the nature of the ancestral snake. Journal of Evolutionary Biology 28: 1309-1320.

https://doi.org/10.1111/jeb.12663

SimÕes B.F., SAmpaio F.L., Douglas R.H., Kodandaramaiah U., CASEwell N.R., HaRrison R.A., Hart N.S., PATRidge J.C., Hunt D.M. \& Gower D.J. (2016). Visual pigments, ocular filters and the evolution of snake vision. Molecular Biology and Evolution 33: 3483-2495.

https://doi.org/10.1093/molbev/msw148

Simon C., Gravelle K., Bissinger B.E., Eiss I. \& Ruibal R. (1981). The role of chemoreception in the iguanid lizard Sceloporus jarrovi. Animal Behavior 29: 46-54.

https://doi.org/10.1016/S0003-3472(81)80150-9

SinERVO B. \& LIVELY C. (1996). The rock-paper-scissors game and the evolution of alternative male strategies. Nature 380: 240-243. https://doi.org/10.1038/380240a0

SOLOMON D.J. (1977). A review of chemical communication in freshwater fish. Journal of Fish Biology 11: 363-376. https://doi.org/10.1111/j.1095-8649.1977.tb04130.x

Steiger S., Schmitt T. \& Schaefer H.M. (2011). The origin and dynamic evolution of chemical information transfer. Proceedings of the Royal Society B 278: 970-979.

https://doi.org/10.1098/rspb.2010.2285

StUART-Fox D.M., MoussalliA. \& Whiting M.J. (2008). Predator-specific camouflage in chameleons. Biology Letters 4: 326-329. https://doi.org/10.1098/rsbl.2008.0173

Susswein A.J. \& NAGLE G.T. (2004). Peptide and protein pheromones in molluscs. Peptides 25: 15231530. https://doi.org/10.1016/j.peptides.2003.11.027

Swaisgood R., Rowe M. \& OwINGS D. (1999). Assessment of rattlesnake dangerousness by California ground squirrels: exploitation of cues from rattling sounds. Animal Behavior 57: 1301-1310. https://doi.org/10.1006/anbe.1999.1095

SYMONDS M.R.E. \& ElgAR M.A. (2008). The evolution of pheromone diversity. Trends in Ecology and Evolution 23: 220-228. https://doi.org/10.1016/j.tree.2007.11.009

TAGA M.E. \& BASSLER B.L. (2003). Chemical communication among bacteria. Proceedings of the National Academy of Sciences 100: 14549-14554. https://doi.org/10.1073/pnas.1934514100

Tinbergen N. (1953). Social Behavior in Animals, with Special Reference to Vertebrates. Methuen Press, London. 
Trabalon M. (2012). Chemical communication and contact cuticular compounds in spider. In: Nentwig W. (ed.) Spider Ecophysiology: 125-140. Springer, Berlin.

TRotier D. \& Døving K. (1998). Anatomical description of a new organ in the nose of domesticated animals by Ludvig Jacobson (1813). Chemical Senses 23:743-754.

https://doi.org/10.1093/chemse/23.6.743

VAN DAMME R. (1999). Evolution of herbivory in lacertid lizards: effects of insularity and body size. Journal of Herpetology 33: 663-674. https://doi.org/10.2307/1565584

VAN DAMME R. \& QUICK K. (2001). Use of predator chemical cues by three species of lacertid lizards. Journal of Herpetology 35: 27-35. https://doi.org/10.2307/1566019

VAN DAMME R. \& VANHOOYDONCK B. (2001). Origins of interspecific variation in lizards sprint capacity. Functional Ecology 15: 186-202. https://doi.org/10.1046/j.1365-2435.2001.00513.x

VAN DAMME R., BAUWENS D. \& VERHEYEN R. (1990). Evolutionary rigidity of thermal physiology: the case of the cool temperate lizard Lacerta vivipara. Oikos 57 (1): 61-67. https://doi.org/10.2307/3565737

VAN DAMme R., AERTS P. \& VANHOOYDONCK B. (1997). No trade-off between sprinting and climbing in two populations of the lizard Podarcis hispanica (Reptilia: Lacertidae). Biological Journal of the Linnean Society 60: 493-503. https://doi.org/10.1006/bij1.1996.0115

VANHOOYDONCK B. \& VAN DAMme R. (1999). Evolutionary relationships between body shape and habitat use in lacertid lizards. Evolution and Ecology Research 1: 785-805.

VANHOOYDOnCK B. \& VAN DAMme R. (2003). Relationships between locomotor performance, microhabitat use and antidepredator behaviour in lacertid lizards. Functional Ecology 17 (2): 160-169. https://doi.org/10.1046/j.1365-2435.2003.00716.x

Vanhooydonck B., Herrel A., Meyers J.J. \& Irschick D.J. (2009). What determines dewlap diversity in Anolis lizards? An among-island comparison. Journal of Evolutionary Biology 22: 293-305. https://doi.org/10.1111/j.1420-9101.2008.01643.x

VERNET-MAURY E. (1980). Trimethylthiazoline in fox feces: a natural alarming substance for the rat. In: VAN DER StARre H. (ed.) Proceedings of the VIIth International Symposium of Olfaction and Taste: 407. IRL Press, London.

Vervust B., VAN Dongen S., GRBAC I. \& VAN DAMme R. (2008). Fluctuating asymmetry, physiological performance, and stress in island populations of the Italian wall lizard (Podarcis sicula). Journal of Herpetology 42: 369-377. https://doi.org/10.1670/07-1202.1

Vervust B., VAn Dongen S., Grbac I. \& VAn Damme R. (2009). The mystery of the missing toes: extreme levels of natural mutilation in island lizard populations. Functional Ecology 23: 996-1003. https://doi.org/10.1111/j.1365-2435.2009.01580.x

VERWAIJEN D. \& VAN DAMME R. (2007a). Correlated evolution of thermal characteristics and foraging strategy in lacertid lizards. Journal of Thermal Biology 32: 388-395.

https://doi.org/10.1016/j.jtherbio.2007.05.005

VERWAIJEN D. \& VAN DAMME R. (2007b). Relationships between chemosensory behaviour and foraging mode within lacertid lizards. Behaviour 144: 83-99. https://doi.org/10.1163/156853907779947373

VERWAIJEN D. \& VAN DAMME R. (2008). Wide home ranges for widely foraging lizards. Zoology 111: 37-47. https://doi.org/10.1016/j.zool.2007.04.001

VitT L.J. \& PiAnKA E.R. (2005). Deep history impacts present-day ecology and biodiversity. Proceedings of the National Academy of Sciences 102: 7877-7881. https://doi.org/10.1073/pnas.0501104102 
VITT L.J. \& PIANKA E.R. (2007). Feeding ecology in the natural world. In: ReILLY S.M., MCBRAYER L.D. \& MiLES D.B. (eds) Lizard Ecology: The Evolutionary Consequences of Foraging Mode: 141-172. Cambridge University Press, Cambridge.

VitT L.J., Pianka E.R., CoOPER W.E. \& SCHWENK K. (2003). History and the global ecology of squamate reptiles. The American Naturalist 162: 44-60. https://doi.org/10.1086/375172

VoGT R.G. \& RIDDIFORD L.M. (1981). Pheromone binding and inactivation by moth antennae. Nature 293: 161-163. https://doi.org/10.1038/293161a0

VON FRISCH K. (1967). The Dance Language and Orientation of Bees. Harvard University Press, Cambridge.

Weber M., MitKo L., Eltz T. \& RAmirez S. (2016). Macroevolution of perfume signalling in orchid bees. Ecology Letters 19: 1314-1323. https://doi.org/10.1111/ele.12667

WEITZMAN S.H. \& FINK S.V. (1985). Xenurobryconin phylogeny and putative pheromone pumps in glandulocaudine fishes (Teleostei: Characidae). Smithsonian Contributions to Zoology 421: 1-121. https://doi.org/10.5479/si.00810282.421

WELDON P.J., FLACHSBARTH B. \& SCHULZ S. (2008). Natural products from the integument of nonavian reptiles. Natural Products Reports 25: 738-56. https://doi.org/10.1039/b509854h

Wever E.G., Vernon J.A., Peterson E.A. \& Crowley D.E. (1963). Auditory responses in the tokay gecko. Proceedings of the National Academy of Sciences 50: 806-811.

https://doi.org/10.1073/pnas.50.5.806

WiLCZYNSKI W., RAND A.S. \& RYAN M.J. (2001). Evolution of calls and auditory tuning in the Physalaemus pustulosus species group. Brain, Behavior and Evolution 58: 137-151.

https://doi.org/10.1159/000047268

WILSON E.O. (1965). Chemical communication in the social insects: insect societies are organized principally by complex systems of chemical signals. Science 149: 1064-1071.

https://doi.org/10.1126/science.149.3688.1064

WiTz B. (1996). A new device for capturing small and medium-sized lizards by hand: the lizard grabber. Herpetological Review 27: 130-131.

WoodLEy S.K. (2010). Pheromonal communication in amphibians. Journal of Comparative Physiology 196: 713-727. https://doi.org/10.1007/s00359-010-0540-6

WYATT T.D. (2010). Pheromones and signature mixtures: defining species-wide signals and variable cues for identity in both invertebrates and vertebrates. Journal of Comparative Physiology 196: 685700. https://doi.org/10.1007/s00359-010-0564-y

WyatT T.D. (2014). Pheromones and Animal Behaviour: Chemical Signals and Signatures. Cambridge University Press, Cambridge.

WyatT T.D. (2015). How animals communicate via pheromones. American Scientist 103: 114-121. https://doi.org/10.1511/2015.113.114

ZHENG Y. \& WIENS J.J. (2016). Combining phylogenomic and supermatrix approaches, and a timecalibrated phylogeny for squamate reptiles (lizards and snakes) based on 52 genes and 4162 species. Molecular Phylogenetics and Evolution 94: 537-547. https://doi.org/10.1016/j.ympev.2015.10.009

Manuscript received: 10 February 2019

Manuscript accepted: 14 June 2019

Published on: 5 July 2019

Branch editor: Ellen Decaesstecker 